\title{
Influence of suspension-feeding bivalves on the pelagic food webs of shallow, coastal embayments
}

\author{
Darcy J. Lonsdale ${ }^{1, *}$, Robert M. Cerrato ${ }^{1}$, Robert Holland ${ }^{1}$, Allison Mass ${ }^{1}$, Lee Holt ${ }^{1}$, \\ Rebecca A. Schaffner ${ }^{2}$, Jerónimo Pan ${ }^{1}$, David A. Caron ${ }^{2}$ \\ ${ }^{1}$ School of Marine and Atmospheric Sciences, Stony Brook University, Stony Brook, New York 11794-5000, USA \\ ${ }^{2}$ Department of Biological Sciences, University of Southern California, 3616 Trousdale Parkway, AHF 309, Los Angeles, \\ California 90089-0371, USA
}

\begin{abstract}
Bivalve and microzooplankton community grazing on natural plankton assemblages were studied in 2 embayments of the Peconic Bay estuary (West Neck Bay, Long Island, New York) to determine the relative importance of each community on plankton mortality. Each embayment was characterized by a fringing salt marsh. The bivalve populations consisted of a re-stocked population of Mercenaria mercenaria (hard clam) and natural populations of Geukensia demissa (ribbed mussel) and Mya arenaria (soft-shell clam). Short-term (3 h) grazing experiments were conducted between May and October 2003 and 2004 using 59 l plastic buckets mounted on a floating platform at each study site. The total grazing pressure on phytoplankton by bivalves (i.e. percent bay volume cleared per day) was substantial, sometimes approaching or exceeding the daily flushing rate of the embayment, and was similar to microzooplankton grazing pressure. Experimental studies also showed that bivalves removed ciliates and copepod eggs of Acartia tonsa from the plankton. At times, bivalveinduced mortality was likely an important regulatory factor on the zooplankton. These findings demonstrate a complex trophic role for benthic suspension-feeders in shallow, coastal embayments. The effects of restoring shellfish populations will likely be beneficial to overall water quality by ameliorating some effects of eutrophication, but the resultant changes in pelagic food web structure are complex and will be difficult to predict.
\end{abstract}

KEY WORDS: Clam fisheries · Food webs · Long Island · Geukensia demissa · Mercenaria mercenaria $\cdot$ Mya arenaria

\section{INTRODUCTION}

Benthic suspension-feeding bivalves filter plankton and other particulate matter in the water and, when present in high abundances, may provide a number of positive benefits to shallow bays, such as reduced turbidity and improved light availability for seagrass photosynthesis, prevention of unwanted algal blooms, sequestration of nutrients by burial of nitrogen and phosphorous in the form of biodeposits which may benefit cord grass growth, and enhanced denitrification (Jordon \& Valiela 1982, Bertness 1984, Cerrato et al. 2004, Newell 2004, Newell \& Koch 2004). In some cases, the impacts of bivalves on aquatic ecosystems have been well documented during the successful establishment of an exotic species (e.g. the zebra mussel Dreissena polymorpha in the Hudson River; Pace et al. 1998). It is more difficult, however, to establish the impacts of the loss of a once important suspension feeder because of additional environmental changes such as wetland loss or eutrophication. Indeed, there is debate about the efficacy of shellfish restoration for improving water quality in estuaries (Newell 1988, Gerritsen et al. 1994, Pomeroy et al. 2006, Heck \& Valentine 2007).

An expectation of a decline in benthic suspension feeders, however, is that pelagic food web structure has shifted. It has been argued that the decline of ben- 
thic suspension-feeders such as oysters in the Chesapeake Bay has resulted in increased planktonic secondary production (Newell 1988, Jackson et al. 2001). Thus zooplankton grazers may be more abundant and play a larger role in structuring pelagic food webs when bivalve populations are reduced. Micro- and mesozooplankton display considerable feeding selectivity, consuming preferred species of algae and rejecting less desirable species (e.g. Stoecker et al. 1986). These less desirable species of phytoplankton may be less nutritious, toxic, or noxious, such as the brown tide alga Aureococcus anophagefferens.

Populations of large, suspension-feeding bivalves have declined in shallow embayments around Long Island, New York, for a variety of reasons. Stocks of commercially important species of bivalves, such as the hard clam Mercenaria mercenaria (Linnaeus, 1758), are a small fraction of those estimated to have been present 2 to 3 decades ago (Kassner 1993), particularly in Great South Bay on the south shore of Long Island. In addition, the total area of intertidal salt marshes has declined (e.g. New York State Office of Planning Services 1972, O'Connor \& Terry 1972) and it is reasonable to presume that populations of the ribbed mussel Geukensia demissa (Dillwyn, 1817), which is endemic to salt marshes of this region, have declined proportionally.

Several observations suggest that maintaining an overall benthic suspension-feeding clearance rate of approximately 30 to $40 \%$ of bay volume per day is an appropriate restoration target for the shallow embayments on Long Island. Estimates by Kassner (1993) indicate that this level of clearance was present during the mid-1970s, prior to the precipitous decline in the hard clam population in Great South Bay. More recently, mesocosm experiments have demonstrated that this level of hard clam clearance prevented the build-up of phytoplankton biomass and net population growth of brown tide, even when the mesocosms were amended with high nutrient concentrations (Cerrato et al. 2004). Prevention of brown tides by clams could provide a positive feedback for the bivalves by maintaining the dominance of nutritious algae, as well as have beneficial effects on other shellfish and eelgrass by maintaining high overall water quality (Greenfield \& Lonsdale 2002, Gobler et al. 2005, Lonsdale et al. 2007).

Autotrophic biomass and production in the water column is often dominated by small phytoplankton species in Long Island bays. In Great South Bay, for example, Lonsdale et al. (1996, 2006b) found that the $<5 \mu \mathrm{m}$ fraction consistently represented $>80 \%$ of the total chlorophyll a (chl a) present. Dominance of small cells (1 to $4 \mu \mathrm{m}$ plankton) including chlorophytes (e.g. Nannochloris atomus) and cyanobacteria (e.g. Synechococcus spp.) in coastal systems has been associated with eutrophication and poor growth in bivalves (Grizzle et al. 2001). In the absence of historically high abundances of benthic suspension-feeders in these bays, the primary consumers of these small cells are protists such as nanoflagellates and ciliates (mostly $<40 \mu \mathrm{m}$ in cell diameter; Boissonneault-Cellineri et al. 2001).

In the present study we measured and compared the relative grazing impacts on the phytoplankton community of the natural populations of Geukensia demissa and Mya arenaria (Linnaeus, 1758) (soft-shell clam), a restocked population of Mercenaria mercenaria, and microzooplankton in 2 shallow embayments characterized by a fringing salt marsh ( 2 to $3 \mathrm{~m}$ wide). Predation rates of bivalves on microzooplankton (i.e. early life stages of copepods and ciliates) were also measured. Most of what is known about the ecology of salt marshes is derived from studies in meadow marshes (e.g. Geukensia demissa; Jordon \& Valiela 1982, Kemp et al. 1990, Kreeger \& Newell 2000), while there is comparatively little known from fringing salt marshes (Morgan et al. 2009). The goal of the present study was to characterize the impact of suspension-feeding bivalves on plankton community composition, dynamics, and pelagic ecological processes. Our results indicate that the ecological impact of some bivalves in the embayments may not be solely as regulators of primary production but also secondary production.

\section{MATERIALS AND METHODS}

Field site description and hydrography. Two small embayments located within West Neck Bay, Shelter Island (Fig. 1), served as our field sites (hard clam spawning sanctuary and control site) during 2003. The embayments are physically similar, exhibit no temperature stratification, and are characterized by a fringing band of Spartina alternaflora Loisel along the shoreline. The embayments are connected to the larger bay throughout the tidal cycle, and the inlets of both embayments are substantially constricted. The $S$. alterniflora band was approximately 2 to $3 \mathrm{~m}$ wide on all borders except the inlet. At each study site, Geukensia demissa was found along the edge and extended about 1 to $2 \mathrm{~m}$ into the $S$. alterniflora band. Unlike G. demissa, Mercenaria mercenaria initially occurred at low abundance at both sites. This was confirmed in qualitative surveys of the benthic community before hard clam restocking at the sanctuary site (data not shown). During the second year of the present study (2004), we conducted studies only at the sanctuary site, and included Mya arenaria as it had become a dominant member of the bivalve community. Temperature and salinity measurements were 

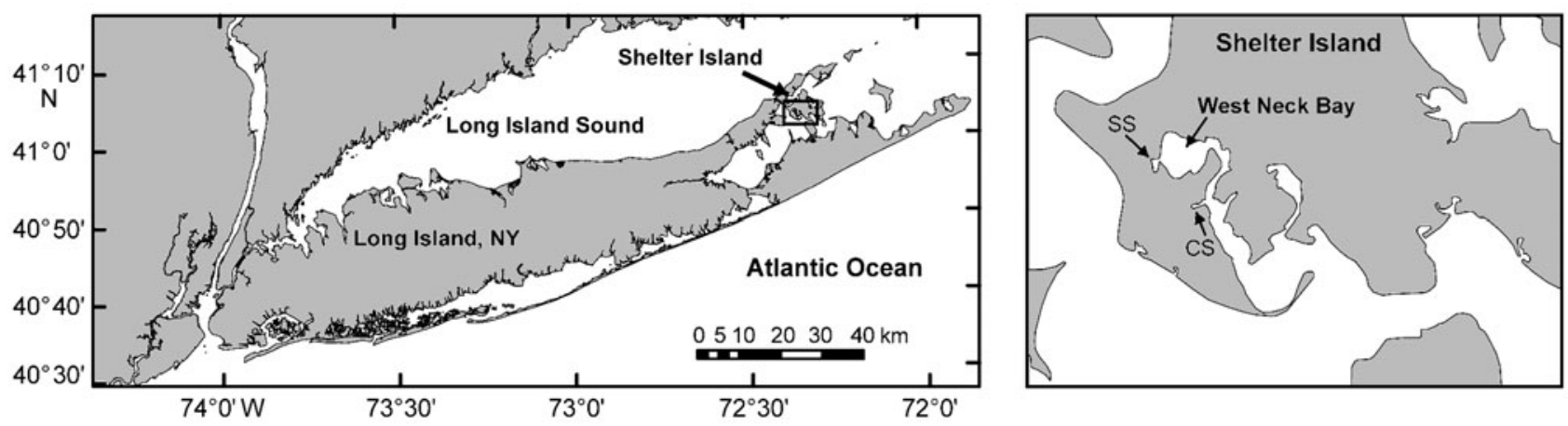

Fig. 1. Study sites in West Neck Bay, Shelter Island, New York, USA. CS: control site; SS: spawning sanctuary for Mercenaria mercenaria

taken throughout the experimental period using a YSI Model 30 salinity, conductivity, and temperature meter.

Bay volume, tidal flushing, and residence time of the control and sanctuary sites in West Neck Bay were determined (Holland 2004). Water depth was measured at random locations using a surveyor's leveling rod and GPS. Perimeter and area were estimated from measurements made with a measuring tape and GPS. Perimeter and area were verified in a GIS using a $1 \mathrm{~m}$ orthoimagery map. Because these bays are not closed systems (i.e. there is continual exchange of seawater with the main channel of West Neck Bay), these measurements were necessary to better assess the feeding impacts of the bivalve populations on the plankton community. The spawning sanctuary had a perimeter of $497 \mathrm{~m}$, an average $( \pm \mathrm{SE})$ depth of $1.03 \pm 0.06 \mathrm{~m}(\mathrm{n}=$ $50)$, an area of $14136 \mathrm{~m}^{2}$, and a volume of $14600 \mathrm{~m}^{3}$. The control basin was $241 \mathrm{~m}$ in perimeter, $0.88 \pm$ $0.05 \mathrm{~m}$ in average depth, $3420 \mathrm{~m}^{2}$ in area, and $3010 \mathrm{~m}^{3}$ in volume. Mean tidal range was $0.54 \mathrm{~m}$. Approximately $101 \%$ of the bay volume of the hard clam sanctuary and $118 \%$ of the control basin were flushed on a daily basis.

Shellfish censuses. The population size of Mercenaria mercenaria in the experimental site was estimated by counting the number of live and dead individuals within $0.25 \mathrm{~m}^{2}$ areas sampled randomly along a series of bottom transects around the embayment using SCUBA. Plots were excavated to $15 \mathrm{~cm}$. Population size in 2003 and 2004 was estimated by adjusting the population at planting (see below), which was well known, by the survival estimate from the SCUBA census. An estimate of the Geukensia demissa population in 2003 and 2004 was obtained by counting individuals within $0.25 \mathrm{~m}$ wide quadrats randomly located around the embayment and multiplying this abundance estimate by the perimeter of the bay. Quadrats were extended from shallow subtidal through the intertidal zone to cover the entire mussel distribution within the fringing cord grass. Size distribution of the ribbed mussel population was also determined by measuring individuals to the nearest mm. A SCUBA census of Mya arenaria was conducted in 2004 at random locations along a series of bottom transects. Abundance estimates were made by gently placing a $0.25 \mathrm{~m}^{2}$ quadrat on the bottom and counting siphons. Plots were then excavated to verify the count.

Hard clam stocking. One of the 2 study sites served as a control and was left unmodified (Fig. 1). The spawning sanctuary (experimental site) was stocked with 'chowder size' Mercenaria mercenaria (approximately 80 to $90 \mathrm{~mm}$ in length) to bring the population to an average density of $15 \mathrm{~m}^{-2}$, a density at which they could potentially account for a significant proportion of total grazing pressure on the phytoplankton community within the confined embayment. Assuming an average depth of $1 \mathrm{~m}$ and a clearance rate of $1 \mathrm{l} \mathrm{h}^{-1}$ clam $^{-1}$ (Hibbert 1977, Doering \& Oviatt 1986), it was estimated that the clams could filter approximately $40 \%$ of the embayment volume each day. This clearance rate by $M$. mercenaria has been shown to prevent the formation of blooms of Aureococcus anophagefferens, the brown tide alga, in experimental mesocosms (Cerrato et al. 2004). The hard clams were planted in fall 2002 by The Nature Conservancy (Long Island Chapter), and clam harvesting was closed in the spawning sanctuary at the same time.

Bivalve feeding. Bivalve feeding experiments were conducted bi-weekly to monthly from May to October 2003 and 2004. Measurements of decreases in total chl $a$ in enclosures containing bivalves were used to estimate individual bivalve clearance rates (l bivalve ${ }^{-1}$ $\mathrm{h}^{-1}$ ) on the total phytoplankton community. Measurements of bivalve feeding on picoplankton (i.e. cyanobacteria [Synechococcus], photosynthetic eukaryotes, and bacteria) were made beginning in July 2003, and feeding on microplankton (>20 $\mu \mathrm{m})$ during 2004. 
Experiments were conducted in 59 l plastic buckets mounted on a floating platform at each study site. Buckets were filled with seawater collected from the sites and anchored within the embayments. Buckets were covered with 2 layers of neutral gray screening during 2003 to reduce light intensity, whereas polystyrene lids were fitted during 2004. Experimental buckets contained either Mercenaria mercenaria (2 to 4 per bucket; mean $\pm \mathrm{SD}$ shell length $=89.0 \pm$ $9.7 \mathrm{~mm}$ and $86.6 \pm 0.9 \mathrm{~mm}$ for 2003 and 2004, respectively), Geukensia demissa (3 to 4 per bucket, shell height $=71.7 \pm 2.6$ and $74.1 \pm 6.3 \mathrm{~mm}, 2003$ and 2004, respectively), or Mya arenaria (4 to 5 per bucket, shell length $=61.5 \pm 8.1 \mathrm{~mm}$ in 2004); 3 replicate buckets were used in each experimental treatment and control.

Experimental shellfish were collected from the study site on the day of the experiment, except for the first 2 experimental dates in 2004 when Mya arenaria were obtained from commercial sources on Shelter Island. Control buckets $(\mathrm{n}=3$ ) were also incubated during each experiment to examine phytoplankton net growth rate in the absence of benthic suspension-feeding. Phytoplankton growth in the control buckets was used to correct estimates of clearance rate within the experimental treatments (Coughlan 1969). After the first 3 experiments in 2003, nutrients $(10 \mu \mathrm{M}$ nitrate, $1 \mu \mathrm{M}$ phosphate) were added to all buckets at the start of each experiment to minimize potential effects of bivalve excretion in experimental buckets on phytoplankton growth. Seawater samples for total chl a, picoplankton, and microplankton were removed from each bucket $1 \mathrm{~h}$ after experimental setup $\left(t_{0}\right)$ to allow time for shellfish to acclimate, and again $4 \mathrm{~h}$ after setup $(t)$.

Bivalve clearance rates $\left(\mathrm{CR}_{i} 1\right.$ bivalve $\left.{ }^{-1} \mathrm{~h}^{-1}\right)$ for total chl $a$ and other planktonic taxa were measured as:

$$
\mathrm{CR}=\frac{V}{n}\left[\frac{\left(\ln C_{0}-\ln C_{t}\right)}{t_{0}}-a\right]
$$

where $V$ is the water volume, $n$ is the number of clams or mussels, $C_{0}$ is the prey density at $t_{0}, C_{t}$ is the prey density at $t$, and $a$ is the cell growth rate (positive or negative) from the control containers (Coughlan 1969).

Seawater samples $(\mathrm{n}=2)$ for total chl a analyses from each bucket at $t_{0}$ and $t$ were collected in brown plastic bottles after gentle mixing of the buckets, stored in coolers with ice packs, and returned to the laboratory for analysis using standard procedures (Parsons et al. 1984) and a Turner Design fluorometer (Model 10-AU). Abundances of picoplanktonic cells $(<4 \mu \mathrm{m})$ were determined by flow cytometry (Olson et al. 1993). Duplicated seawater samples (4.5 ml) were taken at both time points and preserved in gluteraldehyde (1\% final concentration), stored in the cooler, and flash frozen in liquid nitrogen and stored at $-80^{\circ} \mathrm{C}$ when returned to the laboratory. Bacterioplankton, Synechococcus, and photosynthetic picoeukaryotes were enumerated using a FACScalibur $\left(\mathrm{BD}^{\circledR}\right)$ flow cytometer based on fluorescence patterns and particle size determined by forward angle light scatter. Cell abundances of Aureococcus anophagefferens, the brown tide picoplankter, were measured using the monoclonal-antibody technique (Caron et al. 2003)

At each time point, seawater samples $(180 \mathrm{ml}$; $\mathrm{n}=$ 1 per bucket) for microplankton (20 to $200 \mu \mathrm{m})$ were transferred to amber jars, preserved in acidic Lugol's iodine to achieve a final concentration of $10 \%$, and stored in the dark (Stoecker et al. 1994). Samples were processed using standard settling techniques and inverted light microscopy (Utermöhl 1958). Microplankton were grouped into the following taxa: pennate and centric diatoms, flagellates, dinoflagellates, and loricate and non-loricate ciliates. Additionally, dinoflagellates were identified according to Steidinger \& Tangen (1996) and Taylor et al. (2003) and counted using a Sedgewick-Rafter cell which was scanned with an inverted microscope (Olympus CK 2).

The initial densities of eggs and nauplii of the calanoid copepod Acartia tonsa Dana were determined at the beginning of each experimental date from 2 additional 591 buckets that were filled with seawater at the same time as all other buckets. Twenty liters of seawater was removed from each of these 2 additional buckets ( $\mathrm{n}=2$ for $t_{0}$ ) and filtered through a $64 \mu \mathrm{m}$ mesh sieve; the contents on the sieve were preserved in buffered formalin (4\% final concentration). The same seawater volume was also removed from each experimental and control bucket $(n=1)$ at the end of each experiment and processed similarly. Eggs of A. tonsa, total copepod nauplii, and other zooplankton (the latter data not shown) were counted in subsamples taken with a Stemple pipet and viewed with a dissecting microscope. A minimum of 200 organisms were counted for each microzooplankton and mesozooplankton sample (Omori \& Ikeda 1984).

Clearance rates (l bivalve ${ }^{-1} \mathrm{~h}^{-1}$ ) on total chl a were multiplied with population estimates to determine the total clearance capacity $\left(\% \mathrm{~d}^{-1}\right)$ of the bivalve populations. Errors in clearance capacity were obtained from the estimated variables by using approximate formulas for products and quotients of random variables (Mood et al. 1974). In the case of the ribbed mussel populations, individual clearance rates were adjusted for variation in body size because we found a wide range of shell lengths during each census (coefficient of variation $>30 \%$ ). Clearance rate for individuals within each $5 \mathrm{~mm}$ size class present in the census was estimated from an allometric relationship suggested by Winter (1978): 


$$
\mathrm{CR}_{\mathrm{s}}=\left(W_{\mathrm{s}} / W_{\mathrm{m}}\right)^{b} \mathrm{CR}_{\mathrm{m}}
$$

where $\mathrm{CR}_{\mathrm{S}}$ is the estimated clearance rate for the size class, $\mathrm{CR}_{\mathrm{m}}$ is the measured clearance rate per individual, $W_{\mathrm{s}}$ is the estimated dry tissue weight of a mussel in the size class, and $W_{\mathrm{m}}$ the measured dry tissue weight per individual. We used Winter's (1978) estimate of $b=$ 0.76. Allometric relationships between dry tissue weight and shell length were used to estimate $W_{\mathrm{s}}$ for each size class. Ribbed mussels were assumed to feed for $6 \mathrm{~h}$ during a tidal cycle (Kreeger \& Newell 2001). Size adjustment was not necessary for hard or soft-shell clams, as they did not exhibit large variations in shell length (coefficients of variation $=9$ and $11 \%$, respectively). We also assumed they fed throughout the tidal cycle.

Microzooplankton grazing. Microzooplankton grazing experiments (Landry et al. 1995) were conducted to estimate total phytoplankton growth and grazerinduced mortality coefficients. Seawater was gravityfiltered through $0.45 \mu \mathrm{m}$ capsule filters for diluting whole seawater. Experimental dilutions of 100, 75, 50, 25 , and $10 \%$ whole seawater were incubated in situ ( $\sim .25 \mathrm{~m}$ water depth) in triplicate using 1.21 polycarbonate bottles. Dilution bottles were amended with $10 \mu \mathrm{M}$ nitrate and $1.0 \mu \mathrm{M}$ phosphate (Caron et al. 2000). An additional set of whole seawater bottles was incubated without nutrients to assess the impact of nutrient amendments on phytoplankton growth rate and, if necessary, correct the estimate of the phytoplankton growth coefficient. One bottle containing filtered seawater with nutrient additions was also incubated. Whole and filtered seawater were sampled at the beginning of the experiment, and all bottles were sampled ( $\mathrm{n}=2$ for each bottle) after $24 \mathrm{~h}$ incubation for total chl a determination as described above. Regression analyses relating the specific rate of change of total chl a $\left(\mathrm{d}^{-1}\right)$ with dilution treatment were conducted using Excel (Microsoft Office 2000 ${ }^{\circledR}$ ). Community grazing coefficients $(g)$ and prey growth coefficients (k) can be calculated from the slope and $y$-intercept, respectively, of a plot of net growth rate of prey ( $y$-axis) against the fraction of whole water ( $x$-axis).

Statistical analysis. Unless otherwise stated, data were analyzed with a 2-way ANOVA with site or bivalve species as fixed factors and sampling date as a random factor. Prior to ANOVA, the F-max or Bartlett's test was used to test for homogeneity of variances. If standard transformations did not eliminate significant heteroscedasticity, a non-parametric, 2-way ANOVA was used where possible (equal sample sizes were required); the independent variables were experimental date and bivalve species. Unplanned multiple comparisons among means served as a posteriori tests for differences when significant date $\times$ site or date $\times$ bivalve species interactions were present.

\section{RESULTS}

\section{Bivalve population census and chemical/physical factors}

Results of annual bivalve population censuses indicated that approximately $67 \%$ of the planted hard clams survived for a period of $2 \mathrm{yr}$ after planting (Table 1). A substantial fraction of the mortality during the first year probably occurred during the winter after planting because many of the clams failed to burrow. The total abundance of ribbed mussels was lower in the smaller control site compared to the sanctuary site in 2003. In the spawning sanctuary, the total ribbed mussel abundance was lower in the second year and there was a sizeable population of soft-shell clams that was not notable in 2003. There were no notable differences in water temperature between the control and spawning sanctuary sites, and salinity was only slightly lower at the latter location (Fig. 2).

\section{Ambient plankton composition during grazing experiments}

Total chl a $\left(\mu \mathrm{g} \mathrm{l}^{-1}\right)$ concentrations were not significantly different between the spawning sanctuary and control site in 2003 (Table 2, Fig. 3). There was also no difference between years at the spawning sanctuary (nested ANOVA, df $=1,12, F=0.327, \mathrm{p}=0.859$ ) (Fig. 3). Photosynthetic picoeukaryotes were on average 2.7 times more abundant than prokaryotes (Synechococcus) in the spawning sanctuary, whereas the relative abundances of these assemblages were more equitable at the control site, with the picoeukaryotes approximately 1.2 times more abundant than eukaryotes. Overall, the microplankton community was dominated by dinoflagellates comprising on average $61 \%$ of the total community (Fig. 4). The next most abundant taxa were the non-loricate ciliates $(27 \%)$ and tintinnids $(7 \%)$. Pennate diatoms represented $4 \%$ of the total community and centric diatoms $<1 \%$.

Table 1. Mercenaria mercenaria, Geukensia demissa, and Mya arenaria. Mean $( \pm \mathrm{SD}) \times 10^{4}$ total abundances of bivalves within the 2 study sites in West Neck Bay. SS: spawning sanctuary; CS: control site; nm: not measured. $M$. mercenaria were planted in the SS in Fall 2002

\begin{tabular}{|ccccc|}
\hline Year & Site & M. mercenaria & G. demissa & M. arenaria \\
\hline 2002 & SS & 10.0 & $n m$ & $n m$ \\
2003 & SS & $7.3 \pm 5.9$ & $65.1 \pm 29.9$ & $n m$ \\
2004 & SS & $6.6 \pm 11.3$ & $54.2 \pm 17.1$ & $86.9 \pm 66.7$ \\
2003 & CS & $n m$ & $11.4 \pm 8.6$ & $n m$ \\
\hline
\end{tabular}



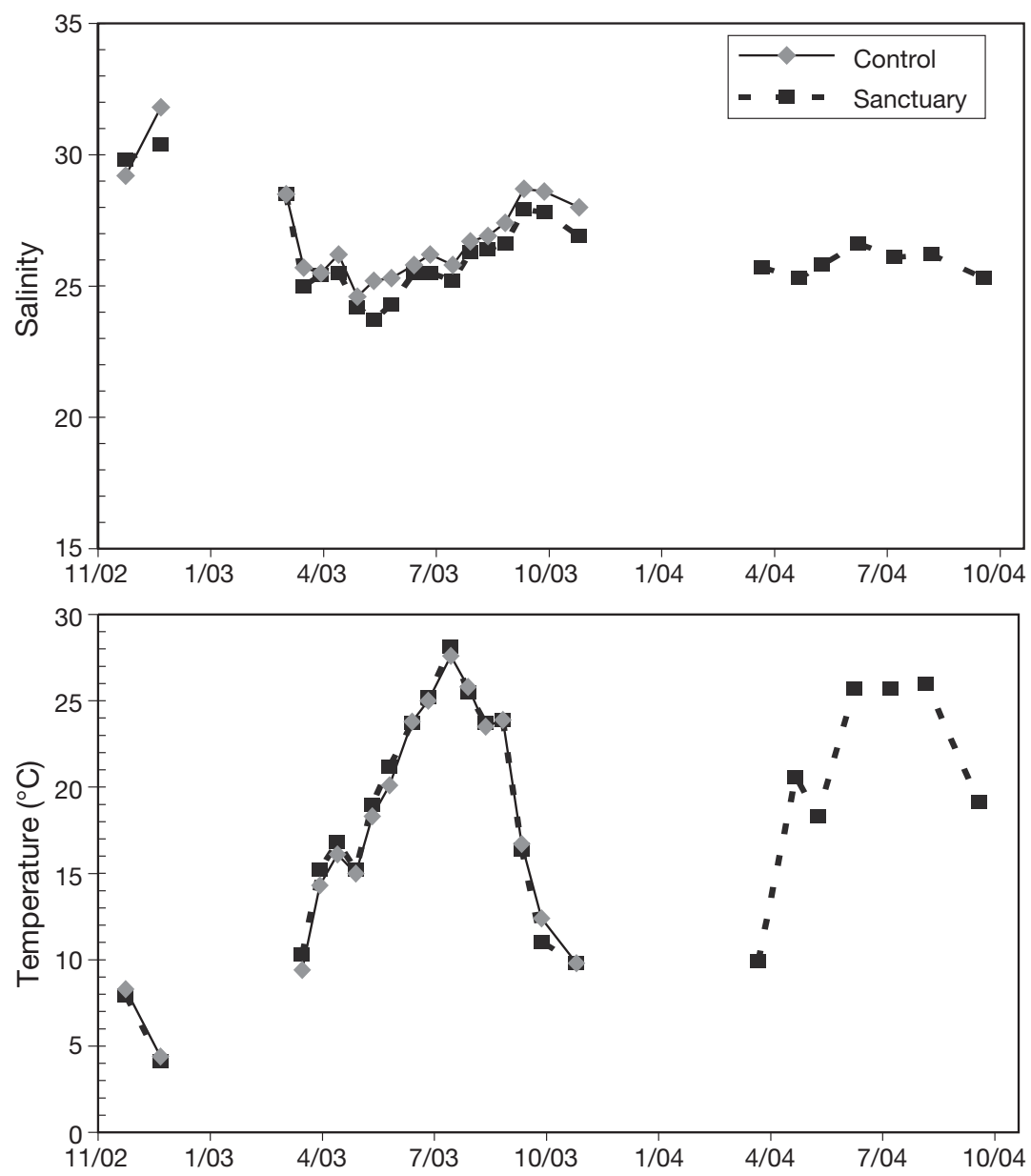

Fig. 2. Water temperature and salinity in West Neck Bay from November 2002 through October 2004

In 2004, dinoflagellates were comprised of 13 genera (data not shown). Among the potentially noxious or toxic dinoflagellates, Prorocentrum minimum, Amphidinium carterae, and Akashiwo sanguinea were most abundant. During June, the dinoflagellate community was comprised of $\sim 60 \%$ non-toxic species and $40 \%$ noxious taxa. Later in the summer, the percent of nontoxic species decreased and heterotrophic forms (i.e. Polykrikos schwartzii and Protoperidinium divergens) became more abundant. The percent of potentially

Table 2. 2-way ANOVA of site differences in total chloro-

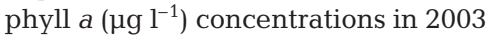

\begin{tabular}{|llrccc|}
\hline & Effect & df & MS & $F$ & $\mathrm{p}$ \\
\hline Site & Fixed & 1 & 0.1207 & 0.1328 & 0.728 \\
Date & Random & 6 & 8.8160 & 9.6948 & 0.007 \\
Date $\times$ Site & Random & 6 & 0.9094 & 4.2883 & 0.003 \\
Error & & 28 & 0.2121 & & \\
\hline
\end{tabular}

noxious species remained fairly constant. In late summer, dinoflagellate cysts were common.

\section{Microzooplankton grazing on the total phytoplankton community}

Significant grazing $\left(g, \mathrm{~d}^{-1}\right)$ on total phytoplankton by zooplankton was detected on all experimental dates, and in general, the highest mortality rates were found during July and August (Table 3). In 2003, there was no significant difference in grazerinduced mortality rates between the spawning sanctuary (seasonal average \pm SD, $\left.g=0.77 \pm 0.49 \mathrm{~d}^{-1}\right)$ and control site $\left(0.69 \pm 0.29 \mathrm{~d}^{-1}\right)$ (Wilcoxon signed-rank test, $T=10, \mathrm{p}>0.1)$.

The overall grazing impact by microzooplankton on total phytoplankton can be gauged by comparing the mortality coefficient $\left(g, \mathrm{~d}^{-1}\right)$ to the specific growth rate $(k$, $\mathrm{d}^{-1}$ ) of phytoplankton (i.e. $g / k_{\text {; }}$ Table 3 ). On average, these values were $0.90 \pm 0.5$ (SD) for the spawning sanctuary (2003 to 2004) and $0.81 \pm 0.37$ for the control site (2003). It has been suggested that dilution experiments may overestimate mortality rates if, at the highest dilution, microzooplankton are dying due to lack of food (Dolan \& McKeon 2005). A re-evaluation of the results with the $10 \%$ whole seawater treatment removed from the regression analyses (data not shown) gave somewhat lower average grazing coefficients $\left(g=0.76 \pm 0.65\right.$ and $0.67 \pm 0.47 \mathrm{~d}^{-1}$, respectively). The re-analysis resulted in a significant reduction in $g$ for the experiments conducted in the spawning sanctuary (Wilcoxon signed-rank test, $T=5$, $\mathrm{p}=0.01$; Sokal \& Rohlf 1981), but not in the control site $(T=8, \mathrm{p}>0.01)$. Using the lower values of $g$, the average (2003 to 2004) grazing impact $(\mathrm{g} / \mathrm{k})$ of microzooplankton in the sanctuary was $0.72 \pm 0.58$. Clearly microzooplankton played a major role as phytoplankton grazers in both embayments.

In general, grazing on brown tide cells per se could not be measured because cell densities in the dilution treatments were below $5000 \mathrm{ml}^{-1}$ (data not shown), the reliable detection limit (Caron et al. 2003). The one exception was on 18 June 2003 at the experimental site when the initial abundance of Aureococcus anophagefferens in whole seawater was $4.1 \times 10^{4}$ cells $\mathrm{ml}^{-1}$. Although zooplankton grazing on the total phytoplankton community was measured $\left(g=0.3 \mathrm{~d}^{-1}\right.$; Table 3$)$, grazing on brown tide cells was not detected ( $p>0.05)$. 

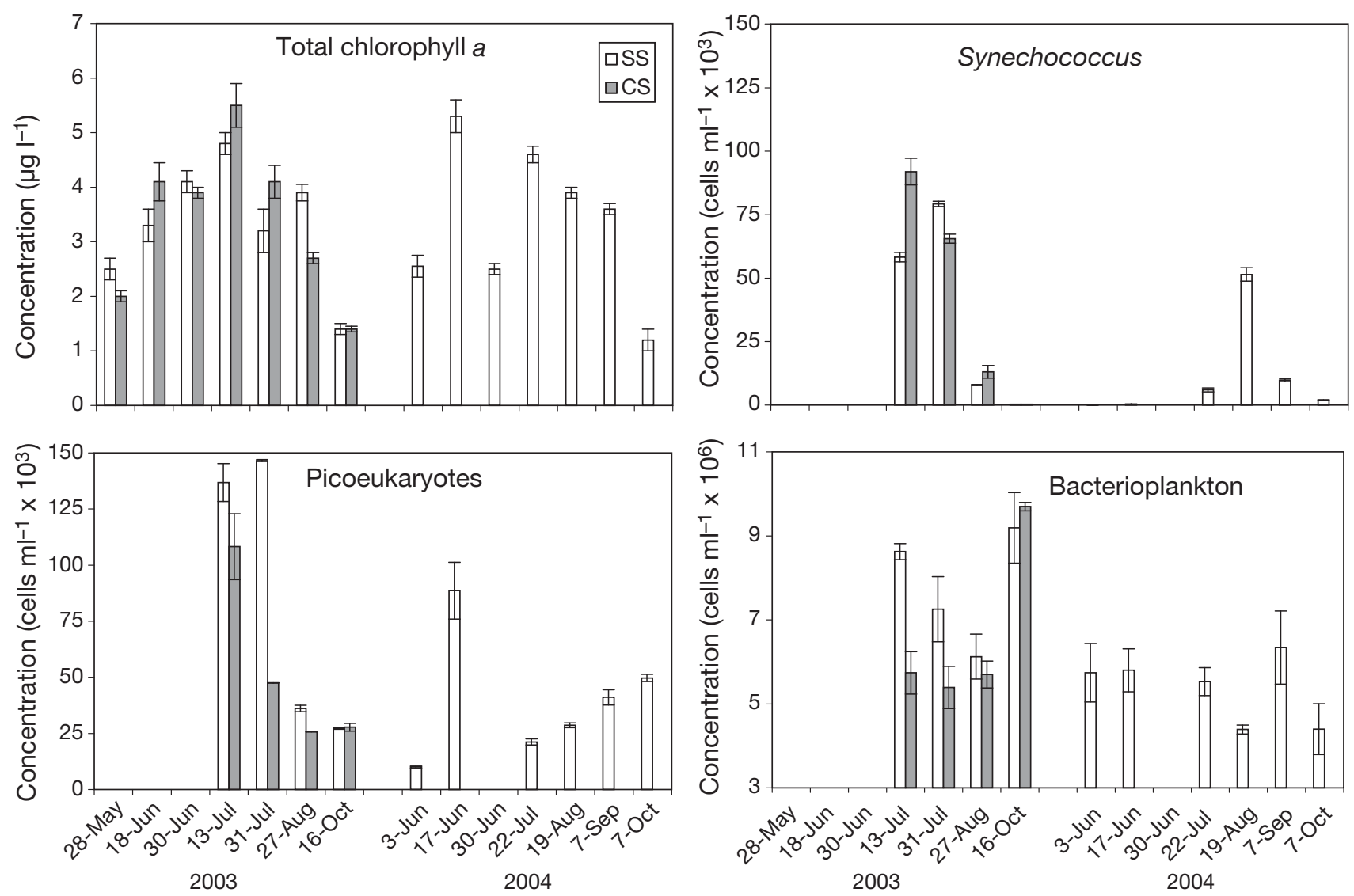

Fig. 3. Initial mean $( \pm \mathrm{SE} ; \mathrm{n}=6)$ concentrations of total chlorophyll $a$, Synechococcus, photosynthetic picoeukaryotes, and bacterioplankton in seawater used in bivalve grazing experiments during 2003 and 2004 at the spawning sanctuary (SS) and during 2003 at the control site (CS). Flow cytometry samples for 30 June 2004 were not processed
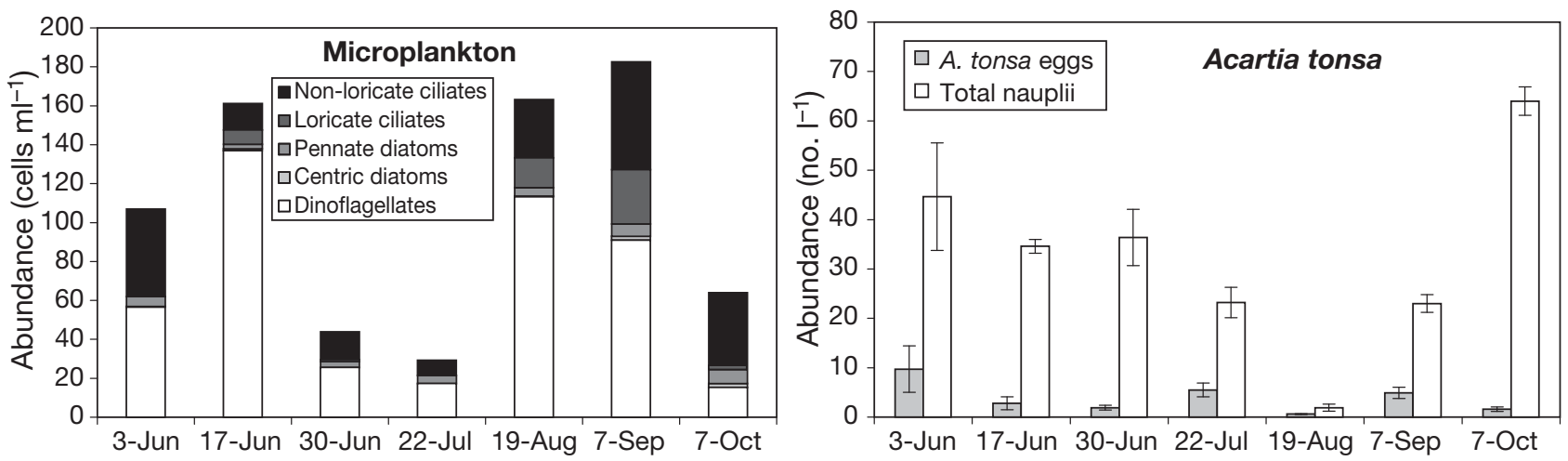

Fig. 4. Initial mean abundances of microplanktonic taxa and Acartia tonsa eggs in bivalve grazing experiments conducted in 2004

\section{Bivalve feeding}

Total phytoplankton community (total chl a)

Geukensia demissa and Mercenaria mercenaria in the sanctuary site during 2003 generally had similar clearance rates on the total phytoplankton community (Table 4, Fig. 5). There were no significant differences in clearance rates of ribbed mussels between the sanctuary and control sites. Averaged over the 2003 season, ribbed mussel clearance rates were $2.3 \pm 1.5 \mathrm{l} \mathrm{h}^{-1}$. Hard clam clearance rates averaged $1.4 \pm 1.6 \mathrm{l} \mathrm{h}^{-1}$. The one experiment where we did not detect any hard clam feeding was 18 June, when brown tide abundance (4.1 $\times 10^{4}$ cells $\mathrm{ml}^{-1}$ ) was above the laboratory-determined threshold for feeding inhibition $\left(\sim 3.5 \times 10^{4}\right.$ cells ml$^{-1}$; 
Table 3. Microzooplankton grazing coefficient $\left(g_{i} \pm \mathrm{SE}_{;} \mathrm{n}=15\right)$ and phytoplankton growth coefficient $\left(k_{i} \pm \mathrm{SE}_{i} \mathrm{n}=15\right)$ determined from dilution experiments at 2 sites in 2003 and 1 site in 2004. SS: spawning sanctuary; CS: control site

\begin{tabular}{|lcccr|}
\hline Date & Site & $\begin{array}{c}g \\
\left(\mathrm{~d}^{-1}\right)\end{array}$ & $\begin{array}{c}k \\
\left(\mathrm{~d}^{-1}\right)\end{array}$ & \\
& & & & \\
\hline 2003 & & & \\
18 Jun & SS & $0.30 \pm 0.11$ & $0.87 \pm 0.07$ & 0.58 \\
& CS & $0.40 \pm 0.04$ & $0.69 \pm 0.03$ & 0.32 \\
30 Jun & SS & $0.62 \pm 0.15$ & $1.05 \pm 0.09$ & 0.45 \\
& CS & $0.82 \pm 0.11$ & $0.61 \pm 0.07$ & -0.22 \\
14 Jul & SS & $0.96 \pm 0.07$ & $0.72 \pm 0.04$ & -0.19 \\
& CS & $0.88 \pm 0.08$ & $0.84 \pm 0.05$ & 0.04 \\
31 Jul & SS & $1.60 \pm 0.22$ & $1.69 \pm 0.13$ & 0.20 \\
& CS & $0.94 \pm 0.15$ & $1.35 \pm 0.09$ & 0.31 \\
28 Aug & SS & $0.86 \pm 0.08$ & $1.05 \pm 0.05$ & 0.24 \\
& CS & $0.88 \pm 0.09$ & $0.95 \pm 0.05$ & 0.09 \\
16 Oct & SS & $0.26 \pm 0.05$ & $0.24 \pm 0.03$ & 0.13 \\
& CS & $0.22 \pm 0.10$ & $0.77 \pm 0.06$ & 0.58 \\
2004 & & & & \\
4 Jun & SS & $0.49 \pm 0.05$ & $1.17 \pm 0.03$ & 0.70 \\
17 Jun & SS & $0.53 \pm 0.12$ & $0.70 \pm 0.07$ & 0.32 \\
30 Jun & SS & $1.06 \pm 0.07$ & $1.30 \pm 0.04$ & 0.27 \\
22 Jul & SS & $2.07 \pm 0.18$ & $2.27 \pm 0.11$ & 0.38 \\
19 Aug & SS & $2.24 \pm 0.16$ & $0.98 \pm 0.10$ & -1.13 \\
7 Sep & SS & $0.31 \pm 0.09$ & $0.89 \pm 0.06$ & 0.66 \\
7 Oct & SS & $0.94 \pm 0.09$ & $0.90 \pm 0.06$ & 0.03 \\
\hline
\end{tabular}
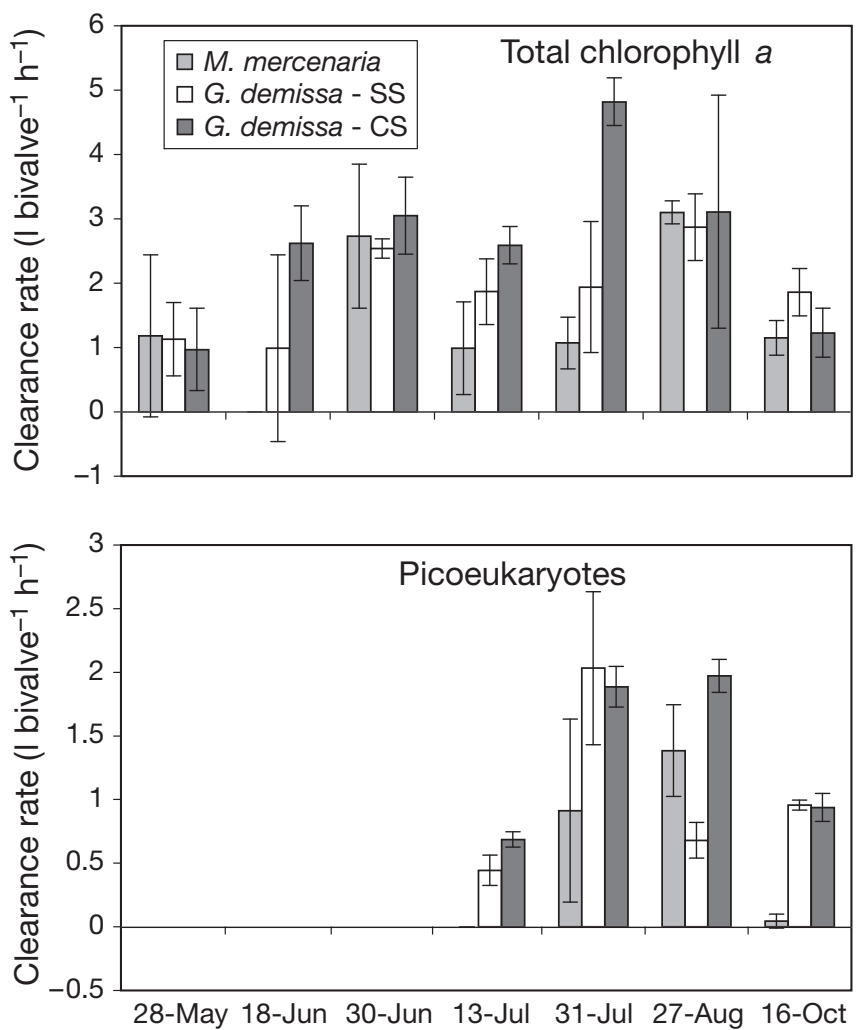

Bricelj et al. 2001). However, a measurable clearance rate was obtained for $G$. demissa on that date.

During 2004, clearance rates of total chl a of ribbed mussels were always greater than rates of either hard or soft-shell clams, and on 3 dates (3 June, 30 June, and 22 July) the differences were significant (Table 4, Fig. 6). For example, during the 30 June experiment, the ribbed mussel clearance rate was 4.5 times greater than either clam species. In contrast, individual clearance rates of hard and soft-shell clams were similar ( $p$ > 0.05 for multiple comparisons among means) and generally $<1.01$ bivalve $^{-1} \mathrm{~h}^{-1}$, with the exception of the 22 July experiment. On 22 July, the hard clam clearance rate was $2.5 \mathrm{l}$ bivalve $^{-1} \mathrm{~h}^{-1}$. Average clearance rates (l bivalve $\mathrm{e}^{-1} \mathrm{~h}^{-1} \pm \mathrm{SD}$ ) of total chl a for the season were $0.8 \pm 1.4,2.9 \pm 2.3$, and $0.6 \pm 0.5$ for hard clams, mussels, and soft-shell clams, respectively.

Clearance rates were combined with population estimates to determine the total clearance capacity of bivalve populations, and the results related to bay volume. In general, West Neck Bay resident mussels were estimated to have a greater clearance capacity of the total phytoplankton community than the planted clams in both years, but Mya arenaria was also an important grazer of total phytoplankton during 2004 (Fig. 7).
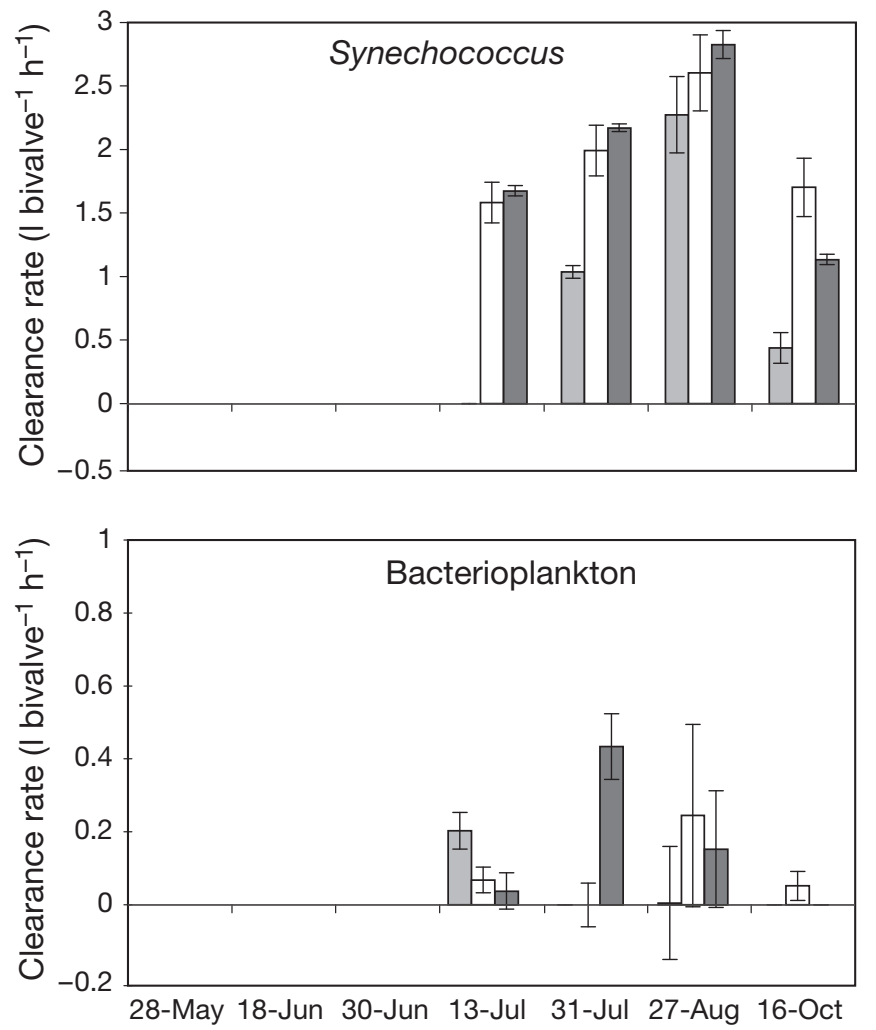

Fig. 5. Geukensia demissa and Mercenaria mercenaria. Mean $\left( \pm \mathrm{SE}_{;} \mathrm{n}=3\right)$ bivalve clearance rates of total chlorophyll a, Synechococcus, photosynthetic picoeukaryotes, and bacterioplankton in 2003. Sampling of picoplankton began on 13 July. Negative clearance rates are shown as zero. CS: control site; SS: spawning sanctuary 
Table 4. 2-way ANOVA of bivalve clearance rates $\left(\mathrm{l} \mathrm{bivalve}^{-1} \mathrm{~h}^{-1}\right)$ on total chlorophyll a (chl a), picoplanktonic cells (Synechococcus, photosynthetic picoeukaryotes, bacterioplankton), and microplankton (dinoflagellates, ciliates, pennate diatoms, and Acartia tonsa eggs). Comparisons were made between Geukensia demissa and Mercenaria mercenaria in 2003 and among G. demissa, M. mercenaria, and Mya arenaria in 2004

\begin{tabular}{|c|c|c|c|c|c|c|c|}
\hline & & & Effect & df & MS & $F$ & $\mathrm{p}$ \\
\hline \multicolumn{8}{|c|}{ Total chl a } \\
\hline \multirow[t]{8}{*}{2003} & Hard clam vs. ribbed mussel & Bivalve & Fixed & 1 & 2.4211 & 3.9243 & 0.095 \\
\hline & Sanctuary site & Date & Random & 6 & 5.0056 & 8.1133 & 0.011 \\
\hline & & Date $\times$ Bivalve & Random & 6 & 0.617 & 0.362 & 0.897 \\
\hline & & Error & & 28 & 1.7043 & & \\
\hline & Ribbed mussels & Site & Fixed & 1 & 5.8666 & 2.7058 & 0.151 \\
\hline & Sanctuary vs. control & Date & Random & 6 & 4.1933 & 1.934 & 0.221 \\
\hline & & Date $\times$ Site & Random & 6 & 2.1682 & 1.1348 & 0.368 \\
\hline & & Error & & 28 & 1.9106 & & \\
\hline \multirow[t]{4}{*}{2004} & Hard, soft, ribbed & Bivalve & Fixed & 2 & 34.079 & 8.1746 & 0.006 \\
\hline & Sanctuary site & Date & Random & 6 & 8.4286 & 2.0189 & 0.141 \\
\hline & & Date $\times$ Bivalve & Random & 12 & 4.1821 & 3.7927 & 0.001 \\
\hline & & Error & & 41 & 1.1026 & & \\
\hline \multicolumn{8}{|c|}{ Synechococcus } \\
\hline \multirow[t]{8}{*}{2003} & Hard clam vs. ribbed mussel & Bivalve & Fixed & 1 & 6.8873 & 13.1406 & 0.036 \\
\hline & Sanctuary site & Date & Random & 3 & 3.3396 & 6.3718 & 0.081 \\
\hline & & Date $\times$ Bivalve & Random & 3 & 0.5241 & 4.1019 & 0.025 \\
\hline & & Error & & 16 & 0.1278 & & \\
\hline & Ribbed mussels & Site & Fixed & 1 & 0.0018 & 0.00885 & 0.931 \\
\hline & Sanctuary vs. control & Date & Random & 3 & 1.9766 & 9.5804 & 0.048 \\
\hline & & Date $\times$ Site & Random & 3 & 0.2063 & 2.4522 & 0.101 \\
\hline & & Error & & 16 & 0.0841 & & \\
\hline \multirow[t]{4}{*}{2004} & Hard, soft, ribbed & Bivalve & Fixed & 2 & 41.935 & 18.6229 & 0 \\
\hline & Sanctuary site & Date & Random & 5 & 16.696 & 7.4147 & 0.004 \\
\hline & & Date $\times$ Bivalve & Random & 10 & 2.2518 & 0.4225 & 0.926 \\
\hline & & Error & & 36 & 5.3296 & & \\
\hline \multicolumn{8}{|c|}{ Picoeukaryotes } \\
\hline \multirow[t]{8}{*}{2003} & Hard clam vs. ribbed mussel & Bivalve & Fixed & 1 & 1.6988 & 1.6246 & 0.292 \\
\hline & Sanctuary site & Date & Random & 3 & 2.3279 & 2.2261 & 0.264 \\
\hline & & Date $\times$ Bivalve & Random & 3 & 1.0457 & 2.5954 & 0.088 \\
\hline & & Error & & 16 & 0.4029 & & \\
\hline & Ribbed mussels & Site & Fixed & 1 & 0.7066 & 1.1048 & 0.37 \\
\hline & Sanctuary vs. control & Date & Random & 3 & 2.1189 & 3.3132 & 0.176 \\
\hline & & Date $\times$ Site & Random & 3 & 0.6395 & 3.7329 & 0.033 \\
\hline & & Error & & 16 & 0.1713 & & \\
\hline \multirow[t]{4}{*}{2004} & Hard, soft, ribbed & Bivalve & Fixed & 2 & 17.085 & 3.357 & 0.077 \\
\hline & Sanctuary site & Date & Random & 5 & 10.672 & 2.0968 & 0.149 \\
\hline & & Date $\times$ Bivalve & Random & 10 & 5.0895 & 3.1123 & 0.006 \\
\hline & & Error & & 36 & 1.6353 & & \\
\hline \multicolumn{8}{|c|}{ Bacterioplankton } \\
\hline \multirow[t]{8}{*}{2003} & Hard clam vs. ribbed mussel & Bivalve & Fixed & 1 & 0.0854 & 1.9176 & 0.26 \\
\hline & Sanctuary site & Date & Random & 3 & 0.1222 & 2.7446 & 0.215 \\
\hline & & Date $\times$ Bivalve & Random & 3 & 0.0445 & 0.6081 & 0.619 \\
\hline & & Error & & 16 & 0.0732 & & \\
\hline & Ribbed mussels & Site & Fixed & 1 & 0.0297 & 0.2273 & 0.666 \\
\hline & Sanctuary vs. control & Date & Random & 3 & 0.0566 & 0.4326 & 0.745 \\
\hline & & Date $\times$ Site & Random & 3 & 0.1307 & 3.2162 & 0.051 \\
\hline & & Error & & 16 & 0.0406 & & \\
\hline \multirow[t]{4}{*}{2004} & Hard, soft, ribbed & Bivalve & Fixed & 2 & 6.1924 & 1.7812 & 0.218 \\
\hline & Sanctuary site & Date & Random & 5 & 0.5898 & 0.1697 & 0.968 \\
\hline & & Date $\times$ Bivalve & Random & 10 & 3.4765 & 1.81 & 0.094 \\
\hline & & Error & & 36 & 1.9207 & & \\
\hline
\end{tabular}


Table 4 (continued)

\begin{tabular}{|c|c|c|c|c|c|c|c|}
\hline & & & Effect & df & MS & $F$ & $\mathrm{p}$ \\
\hline \multicolumn{8}{|c|}{ Dinoflagellates } \\
\hline \multirow[t]{4}{*}{2004} & Hard, soft, ribbed & Bivalve & Fixed & 2 & 73.117 & 6.5865 & 0.01 \\
\hline & Sanctuary site & Date & Random & 6 & 13.396 & 1.2057 & 0.365 \\
\hline & & Date $\times$ Bivalve & Random & 12 & 11.117 & 1.0319 & 0.441 \\
\hline & & Error & & 38 & 10.773 & & \\
\hline \multicolumn{8}{|c|}{ Ciliates } \\
\hline \multirow[t]{4}{*}{2004} & Hard, soft, ribbed & Bivalve & Fixed & 2 & 49.426 & 5.45 & 0.019 \\
\hline & Sanctuary site & Date & Random & 6 & 19.149 & 2.1085 & 0.125 \\
\hline & & Date $\times$ Bivalve & Random & 12 & 9.0907 & 1.0553 & 0.422 \\
\hline & & Error & & 38 & 8.614 & & \\
\hline \multicolumn{8}{|c|}{ Pennate diatoms } \\
\hline \multirow[t]{4}{*}{2004} & Hard, soft, ribbed & Bivalve & Fixed & 2 & 9.2202 & 0.7424 & 0.498 \\
\hline & Sanctuary site & Date & Random & 5 & 22.0245 & 1.7809 & 0.2 \\
\hline & & Date $\times$ Bivalve & Random & 10 & 12.301 & 0.826 & 0.607 \\
\hline & & Error & & 31 & 14.8914 & & \\
\hline \multicolumn{8}{|c|}{ Acartia tonsa eggs } \\
\hline \multirow[t]{4}{*}{2004} & Hard, soft, ribbed & Bivalve & Fixed & 2 & 8.4096 & 0.496 & 0.619 \\
\hline & Sanctuary site & Date & Random & 6 & 51.9378 & 3.0929 & 0.044 \\
\hline & & Date $\times$ Bivalve & Random & 12 & 16.7581 & 0.8212 & 0.628 \\
\hline & & Error & & 34 & 20.4069 & & \\
\hline
\end{tabular}
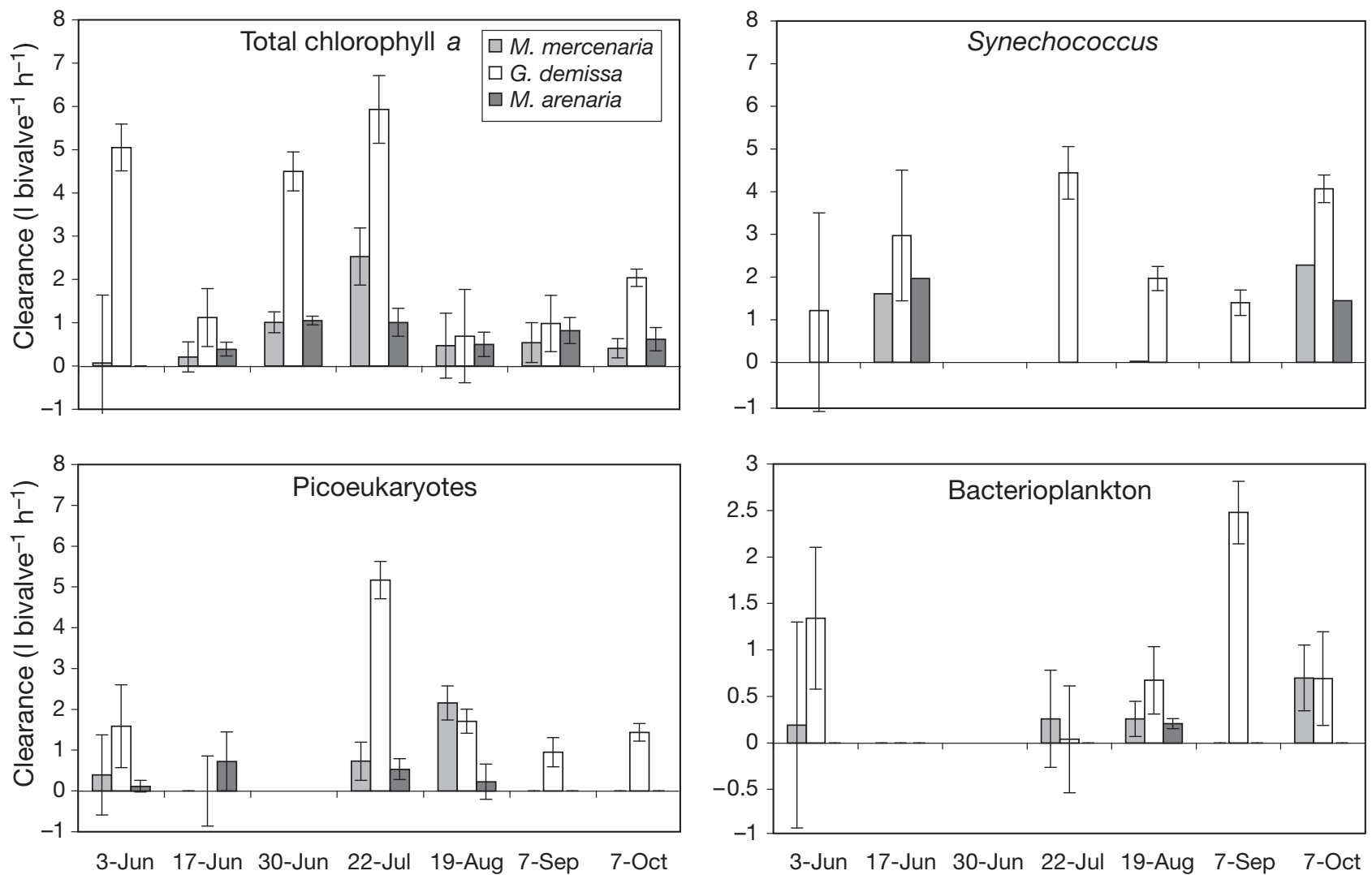

Fig. 6. Geukensia demissa, Mercenaria mercenaria, and Mya arenaria. Mean $( \pm \mathrm{SE} ; \mathrm{n}=3)$ bivalve clearance rates of total chlorophyll a, Synechococcus, photosynthetic picoeukaryotes, and bacterioplankton in the spawning sanctuary during 2004 . Flow cytometry samples for 30 June 2004 were not processed. Negative clearance rates are shown as zero 


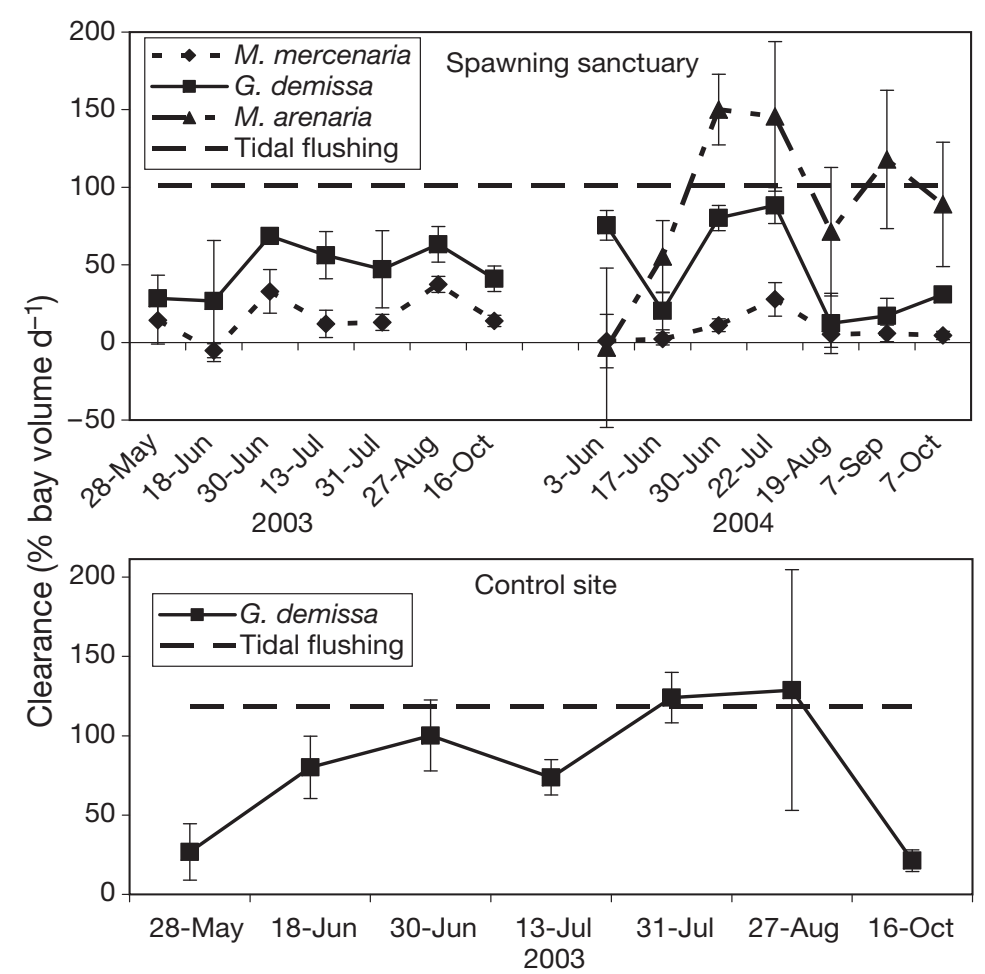

Fig. 7. Geukensia demissa, Mercenaria mercenaria, and Mya arenaria. Mean $( \pm \mathrm{SE})$ clearance capacities of bivalves, determined from total chlorophyll a clearance rates (l bivalve $\left.\mathrm{e}^{-1} \mathrm{~h}^{-1}\right)$ and population abundances ( $\mathrm{n}=3$ for clearance rate, $\mathrm{n}=50$ for bivalve abundance), relative to daily flushing of the control and spawning sites during 2003 and the latter in 2004

Table 5. Geukensia demissa, Mercenaria mercenaria, Mya arenaria. Mean $( \pm \mathrm{SE})$ clearance capacities $\left(\% \mathrm{~d}^{-1}\right)$ of total bivalves on picoplanktonic cells (Synechococcus, photosynthetic picoeukaryotes, and bacterioplankton) determined from clearance rates $\left(1\right.$ bivalve $\left.\mathrm{e}^{-1} \mathrm{~h}^{-1}\right)$ and population abundances $(\mathrm{n}=3$ for clearance rate, $\mathrm{n}=50$ for abundance), relative to daily flushing of the experimental site in 2004

\begin{tabular}{|lccc|}
\hline Date & G. demissa & M. mercenaria & M. arenaria \\
\hline Synechococcus & & & \\
3 Jun & $18 \pm 48$ & 0 & 0 \\
17 Jun & $54 \pm 39$ & $18 \pm 8$ & $282 \pm 187$ \\
22 Jul & $66 \pm 13$ & 0 & 0 \\
19 Aug & $35 \pm 7$ & 0 & 0 \\
7 Sep & $24 \pm 7$ & 0 & 0 \\
7 Oct & $62 \pm 7$ & $25 \pm 8$ & $208 \pm 42$ \\
Photosynthetic picoeukaryotes & & \\
3 Jun & $24 \pm 22$ & $4 \pm 15$ & $17 \pm 29$ \\
17 Jun & 0 & 0 & $4 \pm 147$ \\
22 Jul & $77 \pm 10$ & $8 \pm 8$ & $77 \pm 52$ \\
19 Aug & 0 & $24 \pm 10$ & $33 \pm 88$ \\
7 Sep & $17 \pm 9$ & 0 & 0 \\
7 Oct & $22 \pm 5$ & 0 & 0 \\
Bacterioplankton & & \\
3 Jun & $20 \pm 16$ & $2 \pm 17$ & 0 \\
17 Jun & 0 & 0 & 0 \\
22 Jul & $1 \pm 12$ & $3 \pm 8$ & 0 \\
19 Aug & $12 \pm 9$ & $3 \pm 3$ & $30 \pm 11$ \\
7 Sep & $43 \pm 8$ & 0 & 0 \\
7 Oct & $10 \pm 11$ & $8 \pm 6$ & 0 \\
\hline
\end{tabular}

Picoplankton

A comparison of individual clearance rates of ribbed mussels between the sanctuary and control sites in 2003 showed no difference for any of the picoplanktonic taxa measured (Table 4, Figs. $5 \& 6$ ). With the exception of the 28 August 2003 experiment, ribbed mussels had significantly higher feeding rates on Synechococcus compared to clams during 2003 and 2004 ( $\mathrm{p}<0.05$ for multiple comparisons among means), while there was no significant difference between Mercenaria mercenaria and Mya arenaria ( $p$ > 0.05). Averaged over 2003 and 2004, bivalve clearance rates (l bivalve ${ }^{-1} \mathrm{~h}^{-1}$ ) on Synechococcus were $2.4 \pm 2.2,0.3 \pm 2.2$ and $0.3 \pm 1.7$ for ribbed mussels, hard clams, and soft-shell clams, respectively. There was no significant difference in clearance rates for Geukensia demissa $\left(1.4 \pm 1.8 \mathrm{l} \mathrm{h}^{-1}\right)$, M. mercenaria $(0.1 \pm$ $\left.1.6 \mathrm{l} \mathrm{h}^{-1}\right)$, or $M$. arenaria $\left(0.1 \pm 0.9 \mathrm{l} \mathrm{h}^{-1} ; \mathrm{p}>\right.$ 0.05) feeding on photosynthetic picoeukaryotes in either year. Although the average clearance rate on bacterioplankton was positive for $G$. demissa $\left(0.5 \pm 1.2 \mathrm{l} \mathrm{h}^{-1}\right)$ and on average not detected in hard $\left(-0.1 \pm 1.4 \mathrm{l} \mathrm{h}^{-1}\right)$ or soft-shelled clams $\left(-0.2 \pm 1.0 \mathrm{l} \mathrm{h}^{-1}\right)$, there was no significant difference among the species. In 2004, the clearance capacity of the $G$. demissa population on Synechococcus in the spawning sanctuary ranged between 18 and $66 \% \mathrm{~d}^{-1}$. The population of $M$. arenaria was estimated to have the greatest clearance capacity, $>200 \% \mathrm{~d}^{-1}$, on the cyanobacteria on 2 dates - 17 June and 7 October - but on other dates it had no impact (Table 5).

\section{Microplankton}

Geukensia demissa consistently exhibited feeding on dinoflagellates for the 2004 season (average $=3.4 \pm$ 3.5 [SD] 1 bivalve $\mathrm{b}^{-1} \mathrm{~h}^{-1}$ ) (Fig. 8). The average clearance rates of dinoflagellates by Mercenaria mercenaria $\left(-0.2 \pm 3.8 \mathrm{l} \mathrm{h}^{-1}\right)$ and Mya arenaria $\left(0.8 \pm 2.4 \mathrm{l} \mathrm{h}^{-1}\right)$ were significantly $(p<0.05)$ lower during the season than those by $G$. demissa, and the clam rates were not significantly different $(p<0.05)$ from one another (Table 4, and multiple comparison among means). Bivalve clearance rates of ciliates also were significantly related to bivalve species (Table 4, Fig. 8). Ribbed mussels exhibited higher seasonal clearance rates on ciliates $\left(2.9 \pm 3.5 \mathrm{l}\right.$ bivalve $\left.^{-1} \mathrm{~h}^{-1}\right)$ compared to hard $\left(0.0 \pm 3.5 \mathrm{l} \mathrm{h}^{-1}\right)$ and soft-shell clams $\left(0.6 \pm 2.0 \mathrm{l} \mathrm{h}^{-1}\right)$. The minimum total population clearance capacity of bi- 
Table 6. Geukensia demissa, Mercenaria mercenaria, Mya arenaria. Mean $( \pm \mathrm{SE})$ clearance capacities $\left(\% \mathrm{~d}^{-1}\right)$ of total bivalves on microplanktonic taxa (dinoflagellates, ciliates, and eggs of Acartia tonsa) determined from clearance rates (l bivalve $\left.^{-1} \mathrm{~h}^{-1}\right)$ and population abundances $\left(\mathrm{n}=3,{ }^{*} \mathrm{n}=2,{ }^{* *} \mathrm{n}=1\right.$ for clearance rate and $\mathrm{n}=50$ for abundance), relative to daily flushing of the experimental site in 2004, nd = not determined.

\begin{tabular}{|lccc|}
\hline Date & G. demissa & M. mercenaria & M. arenaria \\
\hline Dinoflagellates & & & \\
3 Jun & $110 \pm 62$ & 0 & 0 \\
17 Jun & $18 \pm 07$ & $13 \pm 08$ & $43 \pm 88$ \\
30 Jun & $96 \pm 19$ & $5 \pm 38$ & $307 \pm 173$ \\
22 Jul & $18 \pm 21$ & 0 & 0 \\
19 Aug & $55 \pm 15$ & $15 \pm 13$ & $258 \pm 209$ \\
7 Sep & $54 \pm 45^{*}$ & 0 & 0 \\
7 Oct & $38 \pm 10$ & $8 \pm 05$ & $430 \pm 253$ \\
Pennate diatoms & & & \\
3 Jun & 0 & 0 & $17 \pm 02^{* *}$ \\
17 Jun & nd & $n d$ & nd \\
30 Jun & 0 & $37 \pm 16$ & $258 \pm 209$ \\
22 Jul & $72 \pm 74$ & 0 & $316 \pm 191$ \\
19 Aug & $62 \pm 41^{*}$ & $37 \pm 12^{*}$ & $359 \pm 182$ \\
7 Sep & $109 \pm 33$ & $30 \pm 09$ & $445 \pm 126^{*}$ \\
7 Oct & $47 \pm 33$ & 0 & $401 \pm 249$ \\
Ciliates & & & \\
3 Jun & $88 \pm 20$ & 0 & 0 \\
17 Jun & $40 \pm 33$ & $9 \pm 14$ & $72 \pm 75$ \\
30 Jun & $82 \pm 41$ & $23 \pm 08$ & $65 \pm 115$ \\
22 Jul & $10 \pm 42$ & 0 & 0 \\
19 Aug & $68 \pm 07$ & $12 \pm 21$ & $344 \pm 125$ \\
7 Sep & 0 & 0 & $43 \pm 162^{*}$ \\
7 Oct & $40 \pm 36$ & $24 \pm 16$ & $258 \pm 127$ \\
Copepod eggs & & & \\
3 Jun & $53 \pm 88$ & $86 \pm 42$ & $1117 \pm 263$ \\
17 Jun & 0 & $12 \pm 62^{*}$ & $275 \pm 530^{*}$ \\
30 Jun & $114 \pm 11^{*}$ & 0 & 0 \\
22 Jul & $101 \pm 70$ & $22 \pm 13$ & $309 \pm 183$ \\
19 Aug & $60 \pm 41$ & $10 \pm 21$ & $290 \pm 200$ \\
7 Sep & $2 \pm 14$ & 0 & 0 \\
7 Oct & 0 & 0 & 0 \\
\hline
\end{tabular}

valves on dinoflagellates was $18 \% \mathrm{~d}^{-1}$ and on ciliates $10 \% \mathrm{~d}^{-1}$, both occurring on 22 July (Table 6 ).

Due to a very low density of pennate diatoms on 16 June (some samples had no cells), we excluded this date for statistical analysis. No significant difference in clearance rate due to bivalve species was found (Table 4). Pennate diatoms were cleared from the plankton assemblage at an average rate of $2.1 \pm 5.9 \mathrm{l}$ bivalve $\mathrm{e}^{-1} \mathrm{~h}^{-1}, 0.8 \pm 2.81 \mathrm{~h}^{-1}$, and $2.3 \pm 1.9 \mathrm{lh}^{-1}$ for ribbed mussels, hard and soft-shell clams, respectively (Fig. 8). Although there was no difference in individual clearance rates among the bivalves, the Mya arenaria population exerted the highest clearance capacity (except on 17 June) on pennate diatoms due to their greater density in the embayment (Table 6).

The overall averages for bivalve clearance rate of eggs of Acartia tonsa were positive for all 3 species, although on 2 dates in late summer and 1 in spring egg predation by clams was not detected; on 1 date each in the spring and late summer mussels were not feeding on eggs either (Fig. 8). In cases where the experimental or control density of eggs was determined to be $<1 \mathrm{l}^{-1}$, clearance rates were calculated assuming a density of 1 egg $\mathrm{l}^{-1}$ which resulted in more realistic (usually lower) estimates of bivalve clearance rates. Also, if the final density of eggs in a bucket was zero, the replicate was removed from the data set. Geukensia demissa cleared A. tonsa eggs at an average rate of $3.0 \pm 4.21$ bivalve $^{-1}$ $\mathrm{h}^{-1}$, while Mercenaria mercenaria and Mya arenaria clearance rates were $1.4 \pm 4.5$ and $2.0 \pm 4.3 \mathrm{l} \mathrm{h}^{-1}$, respectively. There was no significant difference in clearance rates among the bivalve species (Table 4). On all dates the combined bivalve clearance capacity of eggs equaled or exceeded $10 \% \mathrm{~d}^{-1}$ (Table 6).

On most dates in 2004, bivalve predation on total copepod nauplii was not detected and the overall average clearance rates were negative $(-0.55 \pm 4.5 \mathrm{l}$ bivalve $^{-1} \mathrm{~h}^{-1},-0.56 \pm 3.2 \mathrm{l} \mathrm{h}^{-1}$, and $-0.11 \pm 2.6 \mathrm{l} \mathrm{h}^{-1}$ for ribbed mussels, hard and soft-shell clams, respectively). Generally, the results did not change when only early-stage nauplii (NI to NIII) of Acartia tonsa were considered (average clearance rates were $-1.6 \pm$ 5.9 and $-1.3 \pm 4.8 \mathrm{l} \mathrm{h}^{-1}$ for mussels and hard clams, respectively), except for Mya arenaria which, on 4 out of the 7 dates, cleared these prey from the plankton assemblage $\left(0.9 \pm 5.31 \mathrm{~h}^{-1}\right)$.

\section{DISCUSSION}

Although knowledge of the ecological roles of marine bivalves is largely drawn from estuaries with large salt marsh systems, we have shown that bivalve grazing on the autotrophic and heterotrophic components of the plankton is similarly important in relatively small, shallow embayments with only a fringing marsh. For example, in Great Sippewissett Marsh, Massachusetts, Geukensia demissa filtered a volume of water greater than the tidal volume of the marsh on each tidal cycle (Jordon \& Valiela 1982), which is mostly higher than at our sites for the same species. However, the total grazing impact on chl a of all 3 bivalve species, G. demissa, Mercenaria mercenaria, and Mya arenaria, at times exceeded the total volume of the embayments flushed on a daily basis (Fig. 7). Our results also are in agreement with other studies that indicate a complex trophic role for bivalves in coastal environments (e.g. G. demissa; Kreeger \& Newell 2000, Wetz et al. 2002). Complex food web effects are possible since bivalves are not only grazing on primary producers but simultaneously competing with and preying on planktonic secondary producers. For example, heterotrophic protists, a group we suspect will be maximally impacted by bivalve feeding, are an 

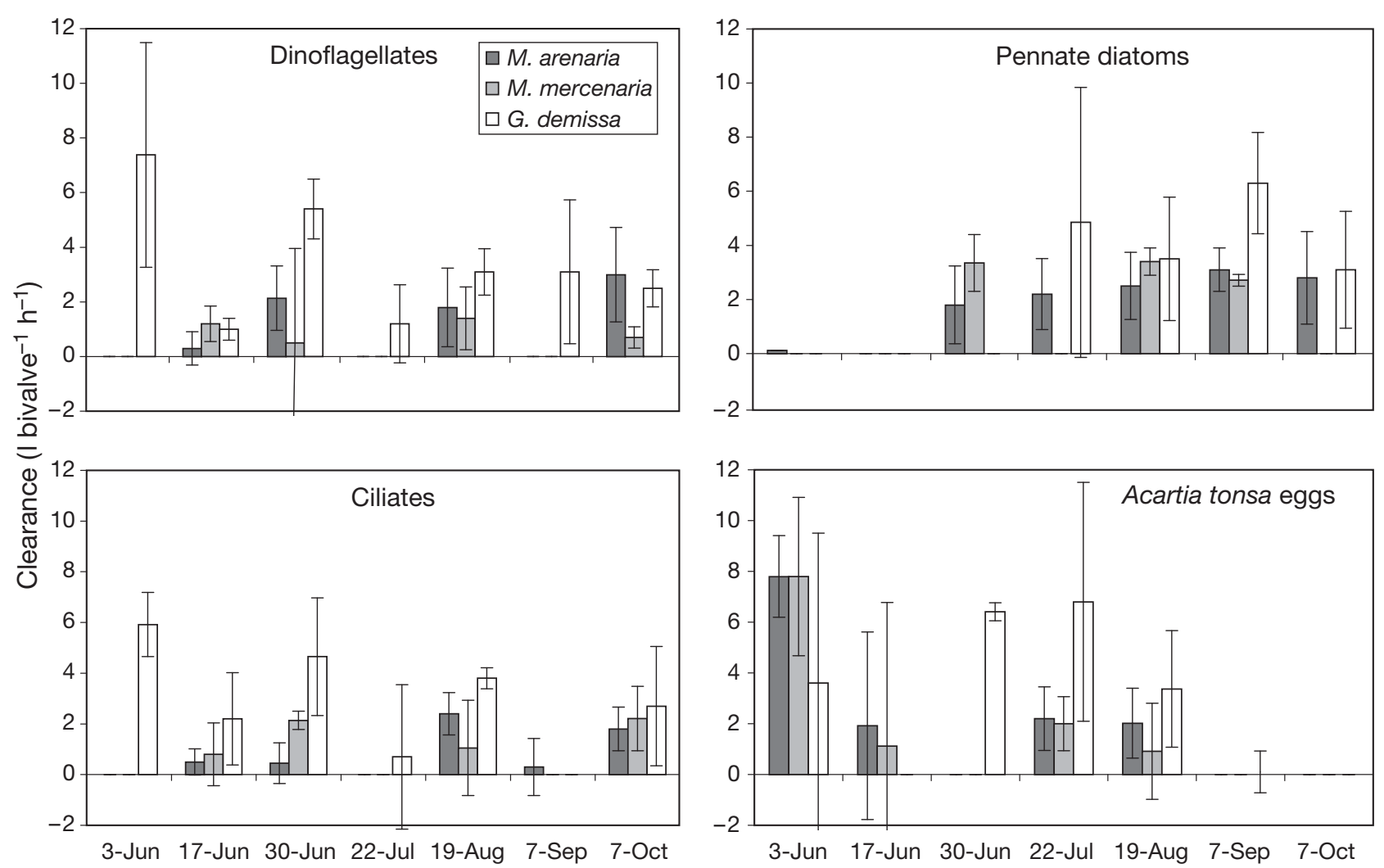

Fig. 8. Geukensia demissa, Mercenaria mercenaria, and Mya arenaria. Mean $( \pm \mathrm{SE})$ bivalve clearance rates of dinoflagellates, ciliates, pennate diatoms, and Acartia tonsa eggs in the spawning sanctuary during 2004 (in general $\mathrm{n}=3$ for clearance rate, but see Table $6, \mathrm{n}=50$ for bivalve abundance). Negative clearance rates are shown as zero

important food resource for other zooplankton such as copepods (Stoecker \& Capuzzo 1990, Lonsdale et al. 1996). Moreover, Acartia tonsa, the dominant copepod in these bays in summer, was shown to be subjected to substantial egg predation by all 3 bivalve species.

\section{Microplankton versus bivalve grazing impacts}

Microzooplankton are significant grazers of phytoplankton in Long Island estuaries and elsewhere (Lonsdale et al. 1996, Boissonneault-Cellineri et al. 2001, Deonarine et al. 2006). Summarizing data from the literature on rates of growth of oceanic phytoplankton and microzooplankton grazing determined from dilution experiments, Calbet \& Landry (2004) found that, on average, microzooplankton consumed $67 \%$ of phytoplankton growth on a daily basis. The present study has shown that the bivalve communities of the embayments of West Neck Bay had grazing impacts on the total phytoplankton ( $\mathrm{chl} \mathrm{a}$ ) community comparable to or exceeding those of microzooplankton (Fig. 7, Table 3). The lowest clearance capacities (percent bay volume cleared per day) of the total bivalve community in the experimental site were $\sim 35$ to $40 \% \mathrm{~d}^{-1}$ in 2003 and $\sim 75 \% \mathrm{~d}^{-1}$ in 2004 when softshell clams were abundant; the lower capacities occurred mostly during the spring and late summer. During the same times, the percent impact of microzooplankton (i.e. $g / k \times 100$ ) on phytoplankton growth was $\sim 35$ to $100 \% \mathrm{~d}^{-1}$. In 2003 in the control site, ribbed mussels cleared a seasonal average of $47 \% \mathrm{~d}^{-1}$ of the embayment compared to $81 \% \mathrm{~d}^{-1}$ by microzooplankton. Our estimates of grazing impacts of bivalves on phytoplankton may be conservative. We selected the same nutrient treatments (nitrate and phosphate) for both the bivalve and microzooplankton grazing studies based on a standard protocol for nutrientreplete conditions in dilution experiments (e.g. Caron et al. 2000). If ammonia excretion by bivalves stimulated the growth of some phytoplankton in the experimental buckets, then clearance rates may have been underestimated. In addition, since our experiments were carried out in unmixed buckets under conditions where the water may have been re-filtered by the bivalves, our clearance rate estimates may be lower than we would have obtained under flow conditions. 


\section{Bivalve impacts on microplankton}

The predation rates on microplankton indicate that bivalves could have had a substantial influence on the net population growth rate of some microplanktonic taxa, including heterotrophs, in the spawning sanctuary in 2004. The maximum daily growth rates of dinoflagellates can range between 1.0 and $3.5 \mathrm{~d}^{-1}$ (Smayda 1997). Additionally, on most dates except 22 July the total clearance of dinoflagellates from bivalve feeding was $>50 \% \mathrm{~d}^{-1}$ and on 2 dates (30 June and 7 October) exceeded $350 \% \mathrm{~d}^{-1}$ (Table 5). Due to their high population density, Mya arenaria on some dates were largely responsible for the high rates of grazing mortality on dinoflagellates, while on other dates dinoflagellate grazing by this clam was not detected. This variable feeding behavior was also true for Mercenaria mercenaria. In contrast, Geukensia demissa consistently exhibited grazing on dinoflagellates, including dates when clams were not feeding. We cannot conclude decisively that the differences in feeding performance on dinoflagellates of the 3 bivalve species reflects differential sensitivity to potentially noxious species which were found at our study site. However, the difference in feeding behavior of hard clams and ribbed mussels (i.e. on 18 June in 2003) in the midst of a modest brown tide $\left(4.1 \times 10^{4}\right.$ cells ml $\left.{ }^{-1}\right)$ suggests this is a possibility.

Population growth rates of planktonic ciliates can exceed $1.0 \mathrm{~d}^{-1}$ during summer months (e.g. 1.2 to $1.55 \mathrm{~d}^{-1}$; Stoecker et al. 1983, Lonsdale et al. 1996) and, as found for dinoflagellates, bivalve-induced mortality in the embayments (Table 6) was sometimes higher than the potential growth rate of ciliates. This result suggests that the bivalves are a major source of mortality for protistan zooplankton and is in accordance with other findings in very different environments. For example, a decline in the abundance of tintinnids was associated with the invasion of the zebra mussel Dreissena polymorpha in the Hudson River, New York (Pace et al. 1998). Also, in a coastal lagoon in the northern Mediterranean, tintinnid abundance was reduced by a factor of 10 at a shellfish culture site compared to waters away from the site (Lam-Hoai et al. 1997). To our knowledge, this is the first report of feeding on planktonic ciliates by Mya arenaria and Mercenaria mercenaria.

\section{Interactions with copepods}

The present study also demonstrated that bivalve predation may directly regulate the population dynamics of copepods, at least of those species which broadcast their eggs as do species of Acartia. At temperatures between 18 and $25^{\circ} \mathrm{C}$, the intrinsic rate of increase of Acartia tonsa ranges from 0.12 to $0.25 \mathrm{~d}^{-1}$
(T. Kiørboe pers. comm.) which also, at times, would have been exceeded by the clearance capacity of the bivalves (Table 6). The present study did not, however, detect bivalve predation on total copepod nauplii (NI to NVI) or earlier naupliar stages (NI to NIII) with the exception of Mya arenaria on several dates. These results are in contrast to studies indicating that other mussels, i.e. Mytilus edulis and Perna canaliculus (Davenport et al. 2000, Zeldis et al. 2004), and clams Corbula (Potamocorbula) amurensis (Kimmerer et al. 1994) prey on crustacean zooplankton, including copepod nauplii. In laboratory studies, Jonsson et al. (2009) found an inverse relationship between water turbulence and the ability of various developmental stages of $A$. tonsa to escape being filtered by M. edulis. Their results suggest that under turbulent conditions copepods have a reduced ability to detect the inhalant water current from mussel filtering. And, because water turbulence kept the eggs suspended in the water column, clearance rate on $A$. tonsa eggs by $M$. edulis also increased with turbulence and reached a maximum of $\sim 3 \mathrm{l} \mathrm{h}^{-1}$ for a $35 \mathrm{~mm}$ mussel. This clearance rate is the same as the mean value we determined for larger Geukensia demissa. Thus the individual bivalve clearance rates and impacts on the $A$. tonsa population in West Neck Bay may be conservative estimates. We do not know, however, if an increase in turbulent water motion in the experimental buckets would have enhanced bivalve clearance of $A$. tonsa nauplii or eggs. Overall, it is appears that bivalves have the ability to substantially regulate the population dynamics of the dominant planktonic microzooplankton (BoissonneaultCellineri et al. 2001) in these shallow embayments.

\section{More evidence for complex benthic-pelagic interactions}

The predation impact on Acartia tonsa eggs found in the present study helps to explain our previous observations in mesocosm experiments (using ambient seawater) in which hard clam abundance was manipulated, and where a negative relationship between hard clams and copepod abundance was found (Lonsdale et al. 2007). At the end of 3 separate experiments, biomasses of nauplii, copepodites, and adults of the dominant copepod, A. tonsa, were lower in tanks with clams compared to controls. Redundancy analysis indicated that total population clearance rate $\left(1 \mathrm{~h}^{-1}\right)$ by Mercenaria mercenaria was the single best predictor of composition of the planktonic community (carbon biomasses of diatoms, dinoflagellates, ciliates, and brown tide were also included in the analysis). Although food (i.e. diatoms and dinoflagellates) limitation could have contributed to low copepod abundance 
in tanks with clam competitors, we hypothesized that these copepod reductions may have resulted from direct predatory impacts of clams on early life stages of A. tonsa and which is now supported by the present study.

In contrast, the predator-prey relationship between hard clams and ciliates reported herein does not match the results from the mesocosm experiments. In the latter, ciliate biomass was positively correlated with total clam clearance rate (Lonsdale et al. 2007). These contradictory results, however, can be explained: despite likely predation by clams, the conditions of no brown tide in the clam tanks likely resulted in much higher ciliate cellular growth and net population growth compared to control tanks without clams in which brown tide developed. In Great South Bay, negative population growth of ciliates was associated with a brown tide (Lonsdale et al. 1996).

\section{Implications of bivalve diversity for shellfish restoration}

Particle retention efficiencies for hard clams decrease below $4 \mu \mathrm{m}$ in diameter (Riisgård 1988), while ribbed mussels are more capable of removing small particles. Geukensia demissa was more efficient at clearing particles in the 0.5 to $2.5 \mu \mathrm{m}$ range than several other bivalve species (Wright et al. 1982), and equally capable of ingesting carbon from small bacteria $(<1 \mu \mathrm{m}$ estimated spherical diameter, ESD) and heterotrophic flagellates (3 to $5 \mu \mathrm{m}$ ESD) (Kreeger \& Newell 1996, 2001; see also Langdon \& Newell 1990, Newell \& Krambeck 1995). Clearance rates $\left(\mathrm{l} \mathrm{h}^{-1} \mathrm{~g}^{-1}\right)$ on phytoplankton (i.e. Isochrysis galbana, $4.8 \mu \mathrm{m}$ ESD) and benthic diatoms (15 $\mathrm{m}$ ESD), however, were higher for ribbed mussels compared to bacteria and heterotrophic protists (see Fig. 1 in Kreeger \& Newell 2001). Our field research has shown that in a natural plankton assemblage both clams and ribbed mussels removed Synechococcus (0.5 to $1 \mu \mathrm{m}$ ESD) and photosynthetic picoeukaryotes (1 to $3 \mu \mathrm{m})$, albeit the mussels were more efficient on Synechococcus. Since the clearance rate estimates for each plankton group were obtained by sampling the same containers, the clam or mussel pumping rate was identical for each of the plankton groups. Differences in clearance rates among the plankton components within a date and treatment reflect, therefore, differences in retention efficiency (RE) and/or escape behavior of motile prey such as copepod nauplii. In West Neck Bay during 2003 and 2004, results for hard and soft-shell clams and ribbed mussels suggested that $\mathrm{RE}_{\text {total chl a }}>\mathrm{RE}_{\text {Synechococcus }}>$ $R E_{\text {picoeukaryotes }}>\mathrm{RE}_{\text {bacterioplankton. }}$ Bacterioplankton were inefficiently filtered, having retention efficiencies that were almost always $<10 \%$ of the values for total chl $a$. G. demissa consistently cleared dinoflagellates, ciliates, and copepod eggs from the water column and at rates comparable to those determined with total chl a. These results contrast with the field study by Kemp et al. (1990), who reported lower removal efficiencies for G. demissa of larger autotrophic cells (diatoms) and heterotrophic cells (ciliates and some dinoflagellates) compared to smaller autotrophic and heterotrophic cells (microflagellates). Other attributes besides cell size, including extracellular metabolites and polysaccharides and microalgal growth phase, also influence particle selection and rejection by G. demissa and other bivalves (reviewed in Pales Espinosa et al. 2008), and could explain the contrasting results.

The present study has shown the potential importance of Geukensia demissa in structuring plankton communities in shallow embayments such as West Neck Bay which may, in part, explain why there were no significant differences in total chl a or microzooplankton grazing rates between the control site (ribbed mussels only) and the spawning sanctuary (ribbed mussel and hard clam populations) in 2003. Any effect of hard clams on the autotrophic and heterotrophic plankton may have been swamped by ribbed mussels and other grazers, including microzooplankton. However, the experiments were conducted using incoming seawater from the main stem of West Neck Bay which likely explains the lack of difference. Nonetheless, the swamping scenario is supported by plankton sampling during ebb flow in the 2 embayments in 2003 (Lonsdale et al. 2006a). Sampling was conducted at 5 locations within each site monthly during the winter (2002 to 2003) when weather permitted, and bi-weekly from April through October. Contrary to our hypothesis that the planted hard clams would impact components of the plankton (e.g. Aureococcus anophagefferens cell abundance), there were no significant differences in abundances between the sites in total chl a, Synechococcus, photosynthetic eukaryotes, or A. anophagefferens; only bacterioplankton differed and it was higher in the spawning sanctuary.

Our results support the idea that multi-species restoration as opposed to single-species stock enhancement may be a better strategy for restoration of some shellfisheries including the hard clam fishery in Long Island bays. Specifically, the results indicate potential positive feedbacks to clams from the feeding activities of ribbed mussels. For example, in comparison to other microalgae, Synechococcus are inefficiently utilized by Mercenaria mercenaria (Bricelj et al. 1984). The cyanobacteria are sorted out and passed to the hind gut and not readily assimilated. Thus the higher filtration capacity of ribbed mussels on these cells and removal from suspension could lead to higher assimilation effi- 
ciencies of hard clams. Our work also suggests the possibility that the feeding behavior of Geukensia demissa in nature is less sensitive to some noxious microalgae, including brown tide and perhaps some dinoflagellates. During a modest brown tide $\left(4.1 \times 10^{4}\right.$ cells ml $\left.^{-1}\right)$ in West Neck Bay, active feeding by ribbed mussels occurred but not by M. mercenaria. This observation is in keeping with laboratory studies showing brown tide had no effect on the ciliary activity of excised gill of $G$. demissa, whereas it caused a decrease in activity of $M$. mercenaria (Gainey and Shumway 1991). If we are correct, ribbed mussels could reduce the incidence of harmful algal blooms in shallow embayments and improve the quality of food for other suspension-feeders. Since ribbed mussels are restricted to intertidal marshes, however, their feeding effects on planktonic community structure would be limited in large bays (Pomeroy et al. 2006). Restoration of commercial shellfish in smaller embayments in which ribbed mussels have a major impact on the plankton community might prove to be a more robust strategy.

Acknowledgements. We gratefully acknowledge the contributions to this project by The Nature Conservancy, Long Island Chapter, which provided funding and facilities at the Mashaumak Preserve, Shelter Island. M. Bortman was instrumental in facilitating funding, and M. Laspia was very helpful in arranging our access to the study sites. This is contribution no. 1382 from the Stony Brook University School of Marine and Atmospheric Sciences.

\section{LITERATURE CITED}

Bertness MD (1984) Ribbed mussels and Spartina alterniflora production in a New England salt marsh. Ecology 65: 1794-1807

Boissonneault-Cellineri KR, Mehta M, Lonsdale DJ, Caron DA (2001) Microbial food web interactions in two Long Island embayments. Aquat Microb Ecol 26:139-155

Bricelj VM, Bass AE, Lopez GR (1984) Absorption and gut passage time of microalgae in a suspension feeder: an evaluation of the ${ }^{51} \mathrm{Cr}:{ }^{14} \mathrm{C}$ twin tracer technique. Mar Ecol Prog Ser 17:57-63

Bricelj VM, MacQuarrie SP, Schaffner RA (2001) Differential effects of Aureococcus anophagefferens isolates ('brown tide') in unialgal and mixed suspensions on bivalve feeding. Mar Biol 139:605-615

Calbet A, Landry MR (2004) Phytoplankton growth, microzooplankton grazing, and carbon cycling in marine systems. Limnol Oceanogr 49:51-57

Caron DA, Dennett MR, Lonsdale DJ, Moran DM, Shalapyonok L (2000) Microzooplankton herbivory in the Ross Sea, Antarctica. Deep-Sea Res 47:3249-3272

> Caron DA, Schaffner RA, Moran DM, Dennett MR and others (2003) Development and application of a monoclonalantibody technique for counting Aureococcus anophagefferens, an alga causing recurrent brown tides in the Mid-Atlantic United States. Appl Environ Microbiol 69: 5492-5502

> Cerrato RM, Caron DA, Lonsdale DJ, Rose JM, Schaffner RA (2004) Effect of the northern quahog Mercenaria merce- naria on the development of blooms of the brown tide alga Aureococcus anophagefferens. Mar Ecol Prog Ser 281: 93-108

Coughlan J (1969) The estimation of filtration rate from the clearance of suspensions. Mar Biol 2:356-358

> Davenport J, Smith RJJW, Packer M (2000) Mussels Mytilus edulis: significant consumers and destroyers of mesozooplankton. Mar Ecol Prog Ser 198:131-137

> Deonarine SN, Gobler CJ, Lonsdale DJ, Caron DA (2006) Role of zooplankton in the onset and demise of harmful brown tide blooms (Aureococcus anophagefferens) in US midAtlantic estuaries. Aquat Microb Ecol 44:181-195

> Doering PH, Oviatt CA (1986) Application of filtration rate models to field populations of bivalves: an assessment using experimental mesocosms. Mar Ecol Prog Ser 31:265-275

Dolan RR, McKeon K (2005) The reliability of grazing rate estimates from dilution experiments: Have we overestimated rates of organic carbon consumption by microzooplankton? Ocean Sci 1:1-7

Gainey LF, Shumway SE (1991) The physiological effect of Aureococcus anophagefferens ('brown tide') on the lateral cilia of bivalve mollusks. Biol Bull 181:298-306

Gerritsen J, Holland AF, Irvine DE (1994) Suspensionfeeding bivalves and the fate of primary production: an estuarine model applied to Chesapeake Bay. Estuaries $17: 403-416$

Gobler CJ, Lonsdale DJ, Boyer GL (2005) A review of the causes, and potential management of harmful brown tide blooms caused by Aureococcus anophagefferens (Hargraves et Sieburth). Estuaries 28:726-749

Greenfield DI, Lonsdale DJ (2002) Mortality and growth of juvenile hard clams Mercenaria mercenaria during brown tide. Mar Biol 141:1045-1050

Grizzle RE, Bricelj VM, Shumway SE (2001) Physiological ecology of Mercenaria mercenaria. In: Kraeuter JN, Castagna M (eds) Biology of hard clams. Elsevier Science, p 305-382

Heck KL Jr, Valentine JF (2007) The primacy of top-down effects in shallow benthic ecosystems. Estuar Coast 30: $371-381$

Hibbert CJ (1977) Energy relations of the bivalve Mercenaria mercenaria from Southampton water. Mar Biol 44:77-84

Holland RD (2004) Assessment of bivalve clearance rates in two small embayments of West Neck Bay, Shelter Island, New York. MS thesis, Stony Brook University, Stony Brook, NY

Jackson JB, Kirby MX, Berger WH, Bjorndal KA and others (2001) Historical overfishing and the recent collapse of coastal ecosystems. Science 293:629-638

> Jonsson A, Nielsen TG, Hrubenja I, Maar M, Petersen JK (2009) Eating your competitor: functional triangle between turbulence, copepod escape behavior and predation from mussels. Mar Ecol Prog Ser 376:143-151

Jordon TE, Valiela I (1982) A nitrogen budget of the ribbed mussel, Geukensia demissa, and its significance in nitrogen flow in a New England salt marsh. Limnol Oceanogr 27:75-90

Kassner J (1993) Possible effects of reduced hard clam abundance in Great South Bay. On the Water July/Aug:4-5

> Kemp PF, Newell SY, Krambeck C (1990) Effects of filterfeeding by the ribbed mussel Geukensia demissa on the water-column microbiota of a Spartina alterniflora saltmarsh. Mar Ecol Prog Ser 59:119-131

> Kimmerer WJ, Gartside E, Orsi JJ (1994) Predation by an introduced clam as the likely cause of substantial declines in zooplankton of San Francisco Bay. Mar Ecol Prog Ser 113:81-93

Kreeger DA, Newell RIE (1996) Ingestion and assimilation of 
carbon from cellulolytic bacteria and heterotrophic flagellates by the mussels Geukensia demissa and Mytilus edulis (Bivalvia, Mollusca). Aquat Microb Ecol 11:205-214

Kreeger DA, Newell RIE (2000) Trophic complexity between producers and invertebrate consumers in salt marshes. In: Weinstein MP, Kreeger DA (eds) Concepts and controversies in tidal marsh ecology. Kluwer, Dordrecht, p $187-220$

Kreeger DA, Newell RIE (2001) Seasonal utilization of different seston carbon sources by the ribbed mussel, Geukensia demissa (Dillwyn) in a mid-Atlantic salt marsh. J Exp Mar Biol Ecol 260:71-91

Lam-Hoai T, Rougier C, Lasserre G (1997) Tintinnids and rotifers in a northern Mediterranean coastal lagoon. Structural diversity and function through biomass estimations. Mar Ecol Prog Ser 152:13-25

Landry MR, Kirshtein J, Constantinou J (1995) A refined dilution technique for measuring the community grazing impact of microzooplankton, with experimental tests in the central equatorial Pacific. Mar Ecol Prog Ser 120:53-63

Langdon CJ, Newell RIE (1990) Utilization of detritus and bacteria as food sources by two bivalve suspensionfeeders, the oyster Crassostrea virginica and the mussel Geukensia demissa. Mar Ecol Prog Ser 58:299-310

Lonsdale DJ, Cosper EM, Kim WS, Doall M, Divadeenam A, Jonasdottir SH (1996) Food web interactions in the plankton of Long Island bays, with preliminary observations on brown tide effects. Mar Ecol Prog Ser 134:247-263

Lonsdale DJ, Cerrato RM, Caron DA (2006a) A field test of hard clams for the prevention of brown tides. Final Report to The Nature Conservancy, Long Island Chapter

> Lonsdale DJ, Greenfield DI, Hillebrand EM, Nuzzi R, Taylor GT (2006b) Contrasting microplanktonic composition and food web structure in two coastal embayments (Long Island, NY, USA). J Plankton Res 28:891-905

Lonsdale DJ, Cerrato RM, Caron DA, Schaffner RM (2007) Zooplankton changes associated with grazing pressure of northern quahogs (Mercenaria mercenaria L.) in experimental mesocosms. Estuar Coast Shelf Sci 73:101-110

Mood AM, Graybill FA, Ross DC (1974) Introduction to the theory of statistics. McGraw-Hill, New York

Morgan PA, Burdick DM, Short FT (2009) The functions and values of fringing salt marshes in Northern New England, USA. Estuar Coast 32:483-495

New York Office of Planning Services (1972) Long Island marine wetlands: status, value, and preservation potentials. Metropolitan New York District Office, Office of Planning Services in Cooperation with the New York State Department of Environmental Conservation, Albany, NY

Newell R (1988) Ecological changes in Chesapeake Bay: Are they the result of overharvesting the American oyster, Crassostrea virginica? In: Lynch MP, Krome EC (eds) Understanding the estuary: advances in Chesapeake Bay research. Chesapeake Bay Research Consortium, Solomons, MD, p 536-546

Newell RIE (2004) Ecosystem influences of natural and cultivated populations of suspension-feeding bivalve molluscs: a review. J Shellfish Res 23:51-61

> Newell R, Koch EW (2004) Modeling seagrass density and distribution in response to changes in turbidity stemming from bivalve filtration and Seagrass sediment stabilization. Estuaries 27:793-806

> Newell SY, Krambeck C (1995) Responses of bacterioplankton to tidal inundations of a saltmarsh in a flume and adjacent mussel enclosures. J Exp Mar Biol Ecol 190:79-95

O'Connor JS, Terry OW (1972) The marine wetlands of Nassau and Suffolk counties, New York. Marine Sciences Research Center, State University of New York, Stony
Brook, NY

Olson RJ, Zettler ER, Chisholm SW, Dusenberry JA (1993) Advances in oceanography through flow cytometry. In: Kemp PF, Sherr BF, Sherr EB, Cole JJ (eds) Handbook of methods in aquatic microbial ecology. Lewis Publishers, Boca Raton, FL, p 175-186

Omori M, Ikeda T (1984) Methods in marine zooplankton ecology. John Wiley \& Sons, New York

Pace ML, Findlay SEG, Fischer D (1998) Effects of an invasive bivalve on the zooplankton community of the Hudson River. Freshw Biol 39:103-116

Pales Espinosa E, Allam B, Ford SE (2008) Particle selection in the ribbed mussel Geukensia demissa and the Eastern oyster Crassostrea virginica: effect of microalgae growth stage. Estuar Coast Shelf Sci 79:1-6

Parsons TR, Maita Y, Lalli CM (1984) A manual of chemical and biological methods for seawater analysis. Pergamon Press, Oxford

> Pomeroy LR, D'Elia CF, Schaffner LC (2006) Limits to topdown control of phytoplankton by oysters in Chesapeake Bay. Mar Ecol Prog Ser 325:301-309

> Riisgård HU (1988) Efficiency of particle retention and filtration rate in 6 species of Northeast American bivalves. Mar Ecol Prog Ser 45:217-223

Smayda TJ (1997) Harmful algal blooms: their ecophysiology and general relevance to phytoplankton blooms in the sea. Limnol Oceanogr 42:1137-1153

Sokal RR, Rohlf FJ (1981) Biometry: the principles and practice of statistics in biological research. W.H. Freeman, New York

Steidinger KA, Tangen K (1996) Chapter 3: Dinoflagellates. In: Tomas CR (ed) Identifying marine diatoms and dinoflagellates. Academic Press, San Diego, CA, p 387-584

> Stoecker DK, Capuzzo JM (1990) Predation on protozoa: its importance to zooplankton. J Plankton Res 12:891-908

Stoecker DK, Davis LH, Provan A (1983) Growth of Favella sp. (Ciliata: Tintinnina) and other microzooplankton in cages incubated in situ and comparison to growth in vitro. Mar Biol 75:293-302

Stoecker DK, Cucci TL, Hulburt EM, Yentsch CM (1986) Selective feeding by Balanion sp. (Ciliata: Balanionidae) on phytoplankton that best support its growth. J Exp Mar Biol Ecol 95:113-130

Stoecker DK, Gifford DJ, Putt M (1994) Preservation of marine planktonic ciliates: losses and cell shrinkage during fixation. Mar Ecol Prog Ser 110:293-299

Taylor FJR, Fukuyo Y, Larsen J, Hallegraeff GM (2003) Chapter 15: Taxonomy of harmful dinoflagellates. In: Hallegraeff GM, Anderson DM, Cembella AD (eds) Manual on harmful marine microalgae. UNESCO Publishing, Paris, p 389-432

Utermöhl H (1958) Zur Vervollkommnung der quantitativen Phytoplankton-Methodik. Mitt Int Ver Theor Angew Limnol 9:1-38

Wetz MS, Lewitus AJ, Koepfler ET, Hayes KC (2002) Impact of the Eastern oyster Crassostrea virginica on microbial community structure in a salt marsh estuary. Aquat Microb Ecol 28:87-97

Winter JE (1978) Review on knowledge of suspension-feeding in lamellibranchiate bivalves, with special reference to artificial aquaculture systems. Aquaculture 13:1-33

Wright RT, Coffin RB, Ersing CP, Pearson D (1982) Field and laboratory measurements of bivalve filtration of natural marine bacterioplankton. Limnol Oceanogr 27:91-98

Zeldis J, Robinson D, Ross A, Hayden B (2004) First observations of predation by New Zealand greenshell mussels (Perna canaliculus) on zooplankton. J Exp Mar Biol Ecol 311:287-299 